\title{
Levoglucosan concentrations in ice-core samples from the Tibetan Plateau determined by reverse-phase high-performance liquid chromatography-mass spectrometry
}

\author{
Ping YAO, ${ }^{1,2,3}$ Valérie F. SCHWAB, ${ }^{3,4}$ Vanessa-Nina ROTH, ${ }^{3,4}$ Baiqing $\mathrm{XU},{ }^{1}$ \\ Tandong YAO, ${ }^{1}$ Gerd GLEIXNER ${ }^{3}$ \\ ${ }^{1}$ Institute of Tibetan Plateau Research, Chinese Academy of Sciences, Beijing, China \\ ${ }^{2}$ University of Chinese Academy of Sciences, Beijing, China \\ ${ }^{3}$ Max Planck Institute for Biogeochemistry, Jena, Germany \\ E-mail: vschwab@bgc-jena.mpg.de \\ ${ }^{4}$ Friedrich Schiller University, Jena, Germany
}

\begin{abstract}
Levoglucosan is a unique marker for biomass burning that can be transported in the atmosphere and preserved in archives such as ice cores. A new method to determine the concentrations of levoglucosan in Tibetan ice-core samples using high-performance liquid chromatography with electrospray ionization mass spectrometry (HPLC-ESI/MS) was developed. Levoglucosan was separated from coeluting water-soluble organic compounds using a $\mathrm{C}_{18}$ column with a gradient program from $50 \%$ to $90 \%$ methanol in ultrapure water. An external standard calibration curve $\left(R^{2}=0.9958\right)$ was established by plotting the ion $\mathrm{m} / \mathrm{z} 163[\mathrm{M}+\mathrm{H}]^{+}$peak area versus the amount of analyte. The repeatability ranges between $11 \%$ and $2 \%$ at a concentration around 10 and $150 \mathrm{ng} \mathrm{mL}^{-1}$. The limit of detection was $10 \mathrm{ng} \mathrm{mL}^{-1}$ and the limit of quantification was $40 \mathrm{ng} \mathrm{mL}^{-1}$. Levoglucosan concentrations ranged from 10 to $718 \mathrm{ng} \mathrm{mL}^{-1}$ in the Muztagh Ata ice core and from 10 to $93 \mathrm{ng} \mathrm{mL}^{-1}$ in the Tanggula ice core. These concentrations, up to 1000 times higher than those measured in samples from Antarctic and Greenland, showed the higher vulnerability of the Tibetan Plateau glaciers to biomass burning events.
\end{abstract}

\section{INTRODUCTION}

Natural and man-made biomass burning has a large impact on climate, since it is a major factor in controlling atmospheric particulate matter concentrations that influence global and local climate directly by absorbing and scattering solar and terrestrial radiation, and indirectly by modifying the mechanism of cloud formation (Andreae and Crutzen, 1997; Solomon and others, 2007). Therefore, to further understand past and present climate, there is an urgent need to quantitatively assess variations in the amount of firederived atmospheric particulate matter.

Ice cores provide environmental archives of atmospheric composition and, because of their annual resolution, contain information about climate and environmental events (Wolff and Peel, 1985; Xu and others, 2009a). Glaciers of the Tibetan Plateau hold the largest ice mass after the polar regions. Located at the intersection of the westerly winds and the south Asian monsoon air masses, they are strongly influenced by changes in air mass circulation, and thus have been intensively studied to reconstruct paleoclimate (Morril and others, 2003; Yao and others, 2012). Related studies showed that black carbon (BC) content in ice cores from Tibetan glaciers is particularly high (up to $120 \mathrm{ng} \mathrm{g}^{-1}$ ) and has a significant impact on the observed rapid glacier retreat (Xu and others, 2009b). However, as BC is released in both anthropogenic fossilfuel and burning biomass emissions, its occurrence in ice cores may not be directly used to reconstruct biomass burning events. A reliable proxy to quantify burning biomass emissions could be used to determine the impacts of anthropogenic fossil-fuel burning emissions on the glacier retreat of the Tibetan Plateau.
Levoglucosan and its isomers, mannosan and galactosan, are exclusively produced during cellulose and hemicellulose burning, with levoglucosan largely predominating (Simoneit and others, 1999). Due to its source-specific emission, ubiquity and environmental stability, levoglucosan is seen as the major molecular tracer for biomass burning activities (Fraser and Lakshmann, 2000; Jordan and others, 2006; Kuo and others, 2008).

Detection and quantification of levoglucosan and its isomers in dry samples are commonly performed by gas chromatographic (GC) separation with mass spectrometry (MS) (Simoneit and others, 2000; Leithead and others, 2006; Zhang and others, 2008; Fabbri and others, 2009). However, due to the high polarity of these compounds, GC-MS analyses involve prior derivatization of the hydroxyl groups with a silylation reagent (bis(trimethylsilyl)trifluoroacetamide) which requires very dry conditions. The presence of traces of water causes incomplete derivatization, leading to non-quantitative results and poor chromatography. Recently, liquid chromatography technology has been introduced to detect levoglucosan and other polar organic compounds in aerosol and soil (Gao and others, 2003; Dixon and Baltzell, 2006; Engling and others, 2006; Puxbaum and others, 2007; Lee and others, 2008; Giannoni and others, 2012; Perrone and others, 2012; Piot and others, 2012), offering an opportunity to analyze levoglucosan quickly and precisely from water samples. Schkolnik and others (2005) investigated levoglucosan in rainwater with a photodiode array (PDA) detector, and used ion-exclusion chromatography (IEC) with a high-performance liquid chromatography (HPLC) system to achieve levoglucosan separation. Kawamura and others (2012) used a gas chromatograph with mass 
spectrometer to detect levoglucosan in ice cores from Gorshkov ice cap, Kamchatka, east Russia. However, as these former methods required concentration from a large volume of sample, they were not ideal for low-volume icecore samples.

Gambaro and others (2008) developed a method to quantify levoglucosan (pg mL $\mathrm{mL}^{-1}$ ) in Antarctic ice using HPLC/ electrospray ionization triple quadrupole mass spectrometry (ESI-MS/MS) with an injection volume of $100 \mu \mathrm{L}$. In addition, reversed phase (RP) chromatography with a $\mathrm{C}_{18}$ column has been shown to be suitable for trace analyses of levoglucosan in water samples using electrospray ionization /mass spectrometry (Dye and Yttri, 2005; Gambaro and others, 2008). This method was successfully employed to quantify levoglucosan in snow samples from Greenland (Kehrwald and others, 2012) and in contaminated aerosol samples from urbanized areas (Giannoni and others, 2012; Perrone and others, 2012). However, when applied to the Tibetan icecore samples, this method had a very poor levoglucosan detection limit due to important chromatographic interferences. To quantify levoglucosan in ice cores from the Tibetan Plateau, we thus needed to develop a new HPLC/ ESI-MS method that efficiently separated levoglucosan from the other coeluting water-soluble organic compounds found in these samples. This new method should ensure good chromatographic separation and MS sensitivity, which are difficult to achieve simultaneously because the necessary eluent composition for good separation usually greatly suppressed ionization efficiency (Wan and Yu, 2007). In addition, the method should be easy, fast and applicable to a large number of samples, with minimal handling that may add additional contamination.

\section{EXPERIMENTAL METHODS}

\subsection{Chemicals and reagents}

Levoglucosan (1,6-anhydro- $\beta$-D-glucopryanose) was purchased from Alfa Aesar $\mathrm{GmbH} \&$ Co KG (Karlsruhe, Germany). Galactosan (1,6-anhydro- $\beta$-D-galactopyranose) and mannosan (1,6-anhydro- $\beta$-D-mannopyranose) were obtained from Merck (Darmstadt, Germany). HPLC gradient grade water, methanol $(\mathrm{MeOH})$, acetonitrile $(\mathrm{ACN})$, chloroform $\left(\mathrm{CHCl}_{3}\right)$, formic acid $(\mathrm{HCOOH})$, ammonium formate $\left(\mathrm{NH}_{4} \mathrm{COOH}\right)$ and sodium chloride $(\mathrm{NaCl})$ were also purchased from Merck. The reagents used for preparing standards and analyses had a minimum purity of at least $98 \%$. Ultrapure water with total organic compound (TOC) content within 1.06-2.67 ppb C was obtained from an Aquinity ultrapure water system (Membrapure, Bodenheim, Germany). As commercial water had a higher TOC content ( 10 ppb C) and thus showed higher background intensity, only ultrapure water was used for standard preparation and analyses.

Standard solutions of levoglucosan with different concentrations ranging from 40 to $800 \mathrm{ng} \mathrm{mL}^{-1}$ were diluted from a stock solution of $1000 \mathrm{ng} \mathrm{mL}^{-1}$. Additionally, $1000 \mathrm{ng} \mathrm{mL}^{-1}$ standard solutions of galactosan and mannosan in ultrapure water were prepared to identify the MS/MS spectrum characterizing the different isomers. All standard solutions were prepared in a thoroughly cleaned and well-ventilated fume-hood and stored at $4{ }^{\circ} \mathrm{C}$ in sealed vials. Daily injections showed no degradation of the standards throughout the experimental period. As levoglucosan had been detected in relatively high concentrations in the laboratory atmosphere (up to $0.212 \mathrm{ng} \mathrm{mL}^{-1}$ in cleaned vials left open 24 hours
(Gambaro and others, 2008)), we were particularly careful about possible contamination derived from the laboratory itself. All glass flasks, beakers, pipettes and vials were cleaned with ultrapure water, combusted at $500^{\circ} \mathrm{C}$ for 5 hours and stored with precombusted aluminum foil covers.

\subsection{Experimental set-up}

The chromatographic separation was performed by a 1200 series high-performance liquid chromatography system (Agilent Technologies, Waldbronn, Germany), equipped with a vacuum degasser, a quaternary pump, an isocratic pump, an autosampler and a thermostated column compartment. Considering the low concentration of levoglucosan in ice-core samples, large-volume injection was employed to increase the sensitivity while maintaining accuracy and precision with minimal sample handling (Hogenboom and others, 2000; Chiaia and others, 2008). For this purpose, a $1500 \mu \mathrm{L}$ loop was installed and ten separate injections of $100 \mu \mathrm{L}$ were collected into the loop and subsequently injected onto a Zorbax Eclipse extra dense bonding (XDB) $\mathrm{C}_{18}$ column $(4.6 \mathrm{~mm} \times 150 \mathrm{~mm}, 5 \mu \mathrm{m}$, Agilent, USA) maintained at $45^{\circ} \mathrm{C}$. A mobile phase consisting of $\mathrm{MeOH}$ (solvent A) and ultrapure water (solvent B) was applied as a gradient at a flow rate of $0.2 \mathrm{~mL} \mathrm{~min}^{-1}$. The gradient program was as follows: $0-40 \mathrm{~min}, 50-90 \% \mathrm{~A} ; 40-50 \mathrm{~min}, 90 \% \mathrm{~A}$; 50$51 \mathrm{~min}, 90-50 \%$ A; 51-60 min, 50\% A. Formic acid (1\% v/v) in ultrapure water was added using a T-connector after the chromatographic column by the isocratic pump at a flow rate of $0.05 \mathrm{~mL} \mathrm{~min}^{-1}$.

Elution of the target compounds was monitored using a LCQ Advantage MAX electrospray ionization mass spectrometer (ESI-MS) (Thermo Finnigan, San Jose, CA, USA) equipped with an ion-trap analyzer for single-stage MS/MS analysis. The optimal MS conditions for ESI analysis were as follows: sheath gas flow rate, 20 arb; aux/sweep gas flow rate, $30 \mathrm{arb}$; I spray voltage, $6 \mathrm{kV}$; capillary temperature, $150^{\circ} \mathrm{C}$; capillary voltage, $-10 \mathrm{~V}$; tube lens offset, -100 . The $[\mathrm{M}+\mathrm{H}]^{+}$ions with $\mathrm{m} / \mathrm{z} 163$ were monitored and quantified in positive ion mode. The mass range from $\mathrm{m} / \mathrm{z} 162.0$ to $\mathrm{m} / \mathrm{z}$ 163.5 was designed to enhance the sensitivity of mass detection. Ions were accumulated in the trap for $200 \mathrm{~ms}$ while 30 microscans were summed to generate a full scan acquisition. The Xcalibur analytical station was used to record the chromatographic map and the mass spectrum.

\subsection{Study site, sample collection and preparation}

Ice-core samples from two regions of the Tibetan Plateau were selected to further evaluate our method developed for levoglucosan analysis. Both areas were drilled by scientists from the State Key Laboratory of Cryospheric Science (SKLCS), Lanzhou, China. During July-August 2002, a $71 \mathrm{~m}$ ice core was drilled on a gentle slope in the northwest part of Muztagh Ata glacier $\left(38^{\circ} 17^{\prime} \mathrm{N}, 75^{\circ} 04^{\prime} \mathrm{E} ; 6350 \mathrm{~m}\right.$ a.s.I.; Fig. 1) in the western Tibetan Plateau. In April 2004, a $190 \mathrm{~m}$ ice core was drilled in the accumulation area of Longxiazailongba glacier $\left(33^{\circ} 6.6^{\prime} \mathrm{N}, 92^{\circ} 4.4^{\prime} \mathrm{E} ; 5645 \mathrm{~m}\right.$ a.s.I.; Fig. 1), Tanggula Mountains, central Tibetan Plateau.

Core sections with an average length of $80 \mathrm{~cm}$ from both sites were transported carefully in a frozen state and stored in the cold room $\left(-18^{\circ} \mathrm{C}\right)$ of SKLCS. Each core section was incised longitudinally into four portions, and each portion was cut across its base every $15-20 \mathrm{~cm}$ for the Muztagh Ata ice core (total of 378 samples from surface to $71 \mathrm{~m}$ depth) and $2 \mathrm{~cm}$ for the Tanggula ice core (total of 117 samples 


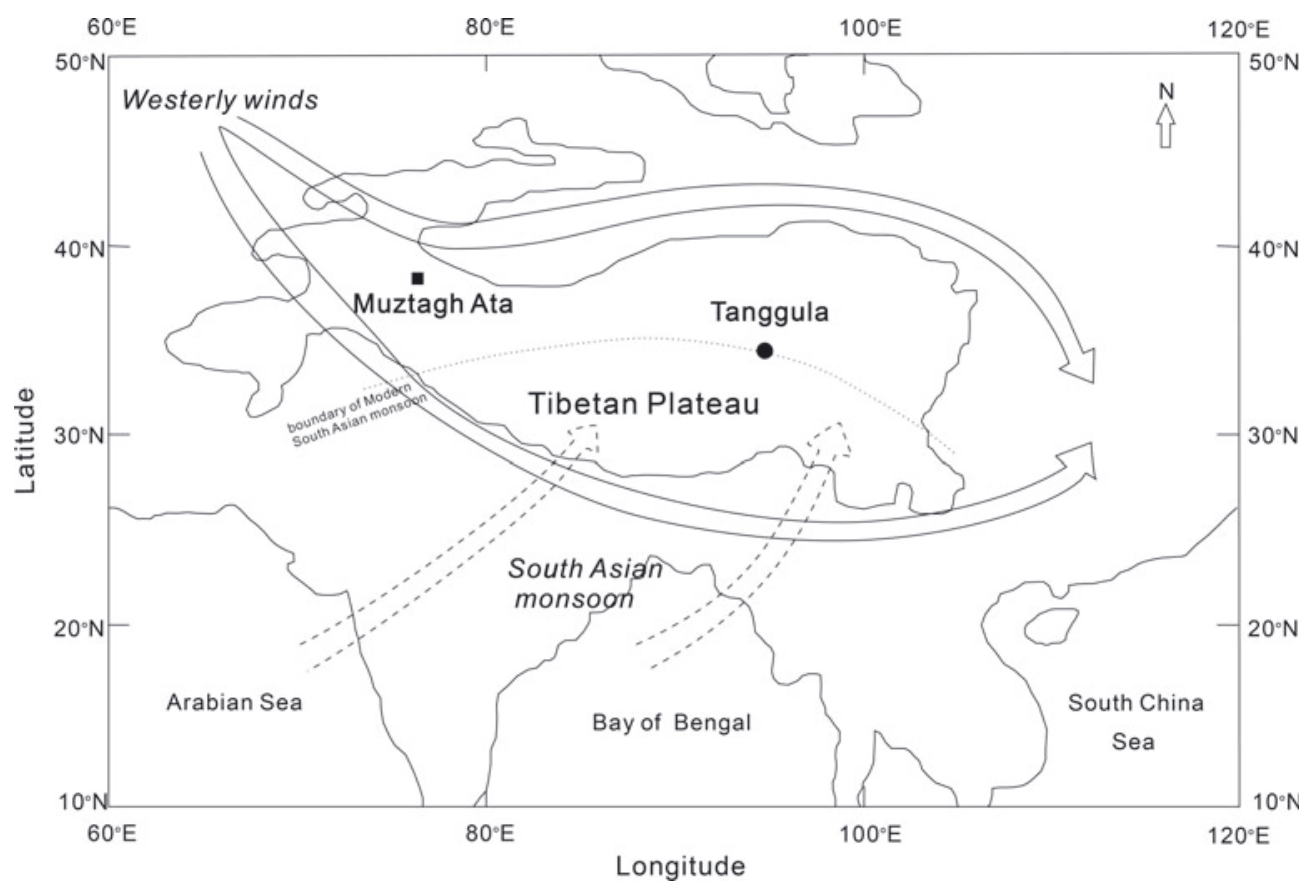

Fig. 1. Map showing the Muztagh Ata ice core (black square) mainly influenced by the westerly winds (solid arrows), and the Tanggula ice core (black dot) in the interactional area of the westerly winds and the south Asian monsoon (dashed arrows), in the Tibetan Plateau. The boundary of the south Asian monsoon is according to Morril and others (2003).

from 1 to $3.5 \mathrm{~m}$ depth) using an ultraclean stainless-steel electronic saw. Approximately $2 \mathrm{~cm}$ of outer ice-core layers were then removed under a class 100 laminar-flow clean bench kept at $-8^{\circ} \mathrm{C}$. Previous work already demonstrated that this pre-treatment is sufficient to avoid contaminations with levoglucosan (Gambaro and others, 2008), soluble ions (Zhao and others, 2011), heavy metals (Li and others, 2006a), organic acid (Wang and others, 2004) and BC (Xu and others, 2009b) from core handling and drilling. The uncontaminated core was melted at room temperature in an ultraclean precombusted $1000 \mathrm{~mL}$ beaker covered with aluminum foil. An aliquot of $15 \mathrm{~mL}$ melted ice was reserved in a clean polyethylene terephthalate (PET) bottle and kept frozen until analysis at the Max Planck Institute for Biogeochemistry, Jena, Germany. Ice-core samples were melted in the storage bottles at room temperature and then directly transferred into the HPLC-autosampler vials. To track possible contamination, we regularly tested blanks of ultrapure water treated the same as the ice samples.

\section{RESULTS AND DISCUSSION}

\subsection{Levoglucosan chromatographic separation}

Recent studies have demonstrated that BC is not inert in the environment (Kaal and Rumpel, 2009). Due to oxidation processes, BC becomes extractable in aqueous solutions, producing a large suite of organic compounds including carbohydrates, short-chain alkanes, different polycyclic aromatic hydrocarbons and $\mathrm{N}$ - and $\mathrm{O}$-containing (poly)aromatics (Kaal and others, 2009). As a result, a large variety of different organic compounds with molecular weight close to that of levoglucosan are expected to be present in Tibetan ice samples.

In samples from the Tibetan Plateau, the Zorbax Eclipse XDB $\mathrm{C}_{18}$ column was found to yield adequate levoglucosan separation and low background intensity. Different solutions of methanol in ultrapure water $(0 \%, 10 \%, 20 \%, 50 \%, 60 \%$, $80 \%, 90 \%, 100 \% \mathrm{v} / \mathrm{v}$ ) were tested as the mobile phase with a standard solution of $100 \mathrm{ng} \mathrm{mL}^{-1}$ levoglucosan. The best signal-to-noise ratio $(\mathrm{S} / \mathrm{N}=120: 1)$ was obtained using a mobile phase of $90 \%$ methanol in ultrapure water giving a levoglucosan elution at $33.7 \mathrm{~min}$ (Fig. 2a). As expected, higher mobile phase polarity decreased levoglucosan retention time. For instance, a mobile phase of pure water caused levoglucosan elution at $15 \mathrm{~min}$ but with a poor $\mathrm{S} / \mathrm{N}$ ratio $(19: 1)$.

The capacity of the isocratic method of $90 \%$ methanol in ultrapure water to purify levoglucosan in highly polluted samples was first tested with a snow sample collected in Jena on 12 January 2010. A sharp and high peak $(\mathrm{S} / \mathrm{N}=3583: 1)$ of levoglucosan, with a baseline separation and the same retention time as the standard (33.7 min) indicated that this isocratic program of $90 \% \mathrm{MeOH}$ in ultrapure water is optimal for the levoglucosan purification in an urban snow sample (Fig. 2b). However, when applied to the ice-core samples from the Tibetan Plateau, this isocratic program showed poor levoglucosan separation, with a low $\mathrm{S} / \mathrm{N}$ ratio $(7: 1)$. The peak area of 3724398 was measured without subtraction of the background (Fig. 2c). The resolution factor between the levoglucosan peak $(\mathrm{m} / \mathrm{z}$ $\left.163[\mathrm{M}+\mathrm{H}]^{+} ; \quad r t=33.7 \mathrm{~min}\right)$ and the first peak of interferences $\left(\mathrm{m} / \mathrm{z} 164[\mathrm{M}=\mathrm{H}]^{+} ; \mathrm{rt}=33.8 \mathrm{~min}\right)$ was 0.1 . The selectivity was close to 1 . In order to separate levoglucosan from undefined compounds, a gradient method from 50\% to $90 \% \mathrm{MeOH}$ in ultrapure water in the first $40 \mathrm{~min}$ was developed. The column was finally rinsed for $10 \mathrm{~min}$ with $90 \% \mathrm{MeOH}$ and re-equilibrated for $10 \mathrm{~min}$ with $50 \%$ $\mathrm{MeOH}$. The total run lasted $60 \mathrm{~min}$ at a flow rate of $0.2 \mathrm{~mL} \mathrm{~min}^{-1}$, with the levoglucosan peak eluting at $31 \mathrm{~min}$. The majority of organic compounds eluted in the first $10 \mathrm{~min}$ and after $40 \mathrm{~min}$. This method showed optimal 

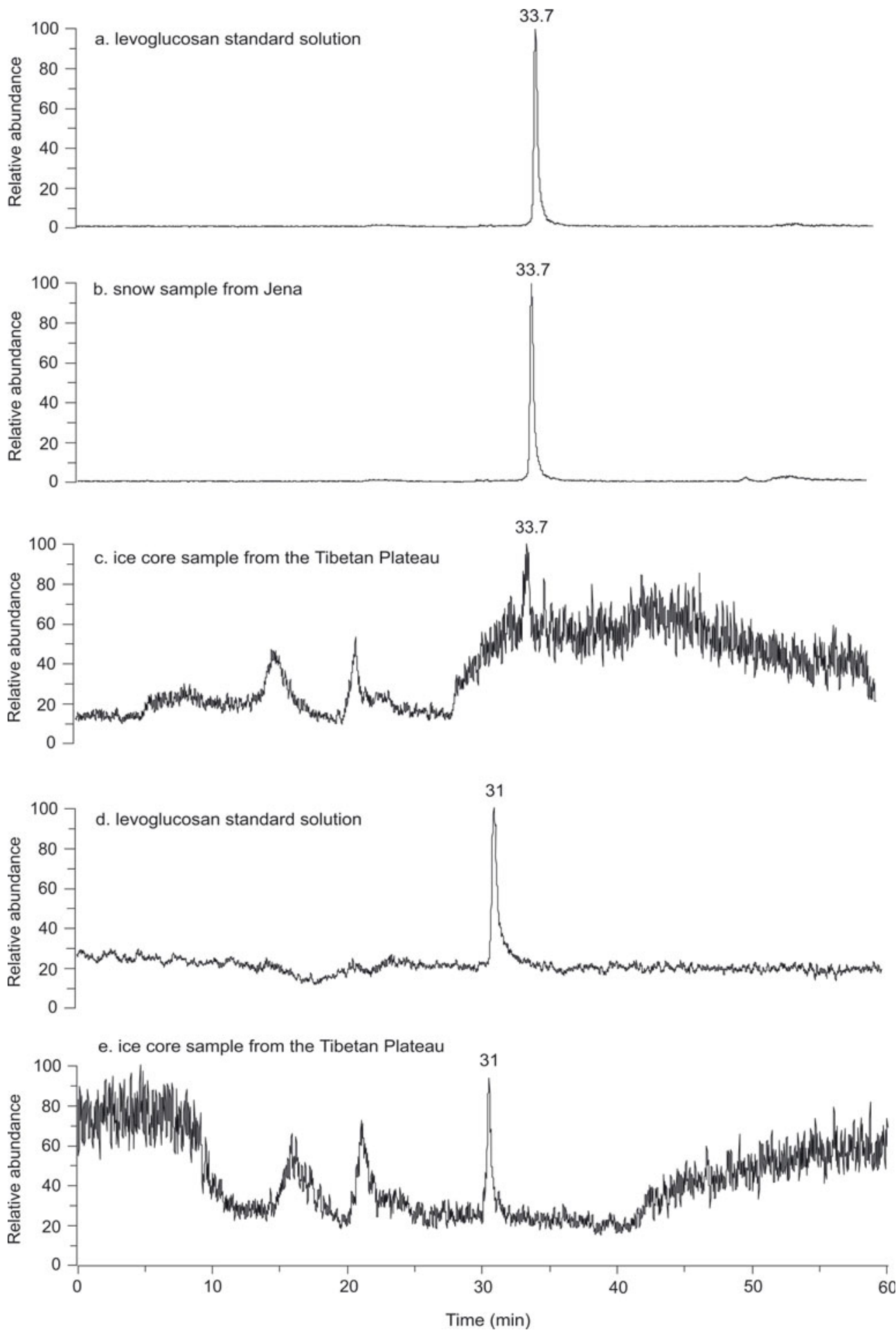

Fig. 2. (a-c) lon chromatogram of a $100 \mathrm{ng} \mathrm{mL}^{-1}$ levoglucosan standard solution (a), Jena snow sample (b) and an ice-core sample from the Tibetan Plateau (c) using the $90 \% \mathrm{MeOH}$ isocratic method. (d, e) lon chromatogram of the same levoglucosan standard solution (d) and the same ice-core sample (e) using the gradient method.

levoglucosan separations in both the levoglucosan standards (Fig. 2d) and the ice-core samples from the Tibetan Plateau (Fig. 2e), with $\mathrm{S} / \mathrm{N}$ ratios of $117: 1$ and $43: 1$ respectively. The levoglucosan peak area of $5.28 \times 10^{-6} \mathrm{mV} \mathrm{s}^{-1}$ was measured without subtraction of the background (Fig. 2e). The resolution and selectivity factors between the levoglucosan peak and the following peak $\left(\mathrm{m} / \mathrm{z} 164[\mathrm{M}=\mathrm{H}]^{+}\right.$; $\mathrm{rt}=40 \mathrm{~min}$ ) were 7.5 and 2.4 , respectively. This gradient program was then successfully applied to 378 ice samples from the Muztagh Ata ice core and 117 samples from the
Tanggula ice core. No shift in the retention time of levoglucosane was observed. Significant chromatographic differences between the snow sample from Jena and icecore samples from the Tibetan Plateau emphasized the importance of efficient chromatographic separation of levoglucosan. Inefficient separation caused important chromatographic interferences that may significantly reduce detection sensitivity, even when scanning over a mass range closely bracketing the target compound (here from $\mathrm{m} / \mathrm{z}$ 162.0 to 163.5$)$. 


\subsection{Optimization of post-column ionization and MS parameters}

The quantification of levoglucosan remains partly an analytical problem, especially if the sugar concentration has to be quantified in ppb concentrations. The main problem is the lack of compatible mobile phase solution that carries out sufficient HPLC separation, with high efficiency of post-column ionization that brings acceptable detection sensitivity. Anhydro-sugars (e.g levoglucosan or sugar alcohols) have a particularly low rate of ionization, so they are difficult to detect using an ESI-MS detector (Wan and Yu, 2007). To handle this problem, strong acid (sulfuric acid) or reducing ions $\left(\mathrm{Cl}^{-}\right)$have been used as reagents (Engelhardt and Ohs, 1987; Zhu and Cole, 2000). However, corrosion of metallic parts or salt accumulation (when using non-volatile salts) in the MS interfaces may cause serious problems of baseline stability and reduced detection sensitivity. Furthermore, when using $\mathrm{MeOH}$, sulfuric acid cannot be used as a post-column reactant, since $\mathrm{MeOH}\left(\mathrm{CH}_{3} \mathrm{OH}\right)$ in reaction with sulfuric acid $\left(\mathrm{H}_{2} \mathrm{SO}_{4}\right)$ forms the ester dimethyl sulphate $\left(\left(\mathrm{CH}_{3}\right)_{2} \mathrm{SO}_{4}\right)$. Consequently, since the MS parameters and the rate of levoglucosan ionization are functions of the chromatographic conditions (solvent, column temperature, reaction time), different reactants for post-column ionization and various MS conditions have been used in previous quantitative studies of levoglucosan (Gao and others, 2003; Palma and others, 2004; Wan and Yu, 2006, 2007; Gambaro and others, 2008).

The ESI sensitivity for different targeted compounds was studied using flow injection analysis. Different reactants, $5 \mathrm{mM}$ of $\mathrm{NH}_{4} \mathrm{COOH}$ (ammonium formate), $5 \mathrm{mM}$ of $\mathrm{NaCl}$ (sodium chloride), $1 \%$ of $\mathrm{HCOOH}$ (formic acid) and pure $\mathrm{CHCl}_{3}$ (chloroform) were added to a $100 \mathrm{ng} \mathrm{mL}^{-1}$ levoglucosan standard solution before the ESI chamber by a T connector using a PHD 4400 Hpsi Programmable Syringe Pump (Harvard Apparatus Inc., Holliston, USA) at a flow rate of $10 \mu \mathrm{L} \mathrm{min}{ }^{-1}$. The intensities of the different adduct ions $\mathrm{m} / \mathrm{z} 180\left[\mathrm{M}+\mathrm{NH}_{4}\right]^{+}, \mathrm{m} / \mathrm{z} 185[\mathrm{M}+\mathrm{Na}]^{+}$and $\mathrm{m} / \mathrm{z} 163$ $[\mathrm{M}+\mathrm{H}]^{+}$in positive ion mode, and $\mathrm{m} / \mathrm{z} 161[\mathrm{M}-\mathrm{H}]^{-}$and $\mathrm{m} /$ z $197[\mathrm{M}+\mathrm{Cl}]^{-}$in negative ion mode were compared to determine the best MS sensitivity relativeto the monitored ions. As a non-volatile salt, $\mathrm{NaCl}$ deposited around the MS interfaces, causing large and rapid decrease of its sensitivity. Therefore, analysis using $\mathrm{NaCl}$ was not pursued further. Lower signals were observed in negative ion mode for both $\mathrm{m} / \mathrm{z} 161[\mathrm{M}-\mathrm{H}]^{-}$and $\mathrm{m} / \mathrm{z} 197[\mathrm{M}+\mathrm{Cl}]^{-}$ions with the absolute intensity of 167 and 142 . In positive mode, the $\mathrm{m} / \mathrm{z}$ $180\left[\mathrm{M}+\mathrm{NH}_{4}\right]^{+}$had an intensity of $1410 \mathrm{mV}$. The $\mathrm{m} / \mathrm{z} 163$ $[\mathrm{M}+\mathrm{H}]^{+}$ion was the most abundant ion, with an absolute intensity of $8440 \mathrm{mV}$, and was thus chosen as the targeted compound.

During method development, the tuning parameters for the ESI source were adjusted to obtain the maximum intensity of $\mathrm{m} / \mathrm{z}[\mathrm{M}+\mathrm{H}]^{+}$. As expected, MS sensitivity was significantly influenced by changes of the spray voltage and temperature of the capillary (Leinonen and others, 2002; Zweiner and others, 2002; Rafaëlly and others, 2008). Spray voltage of $6 \mathrm{kV}$ and capillary temperature of $150^{\circ} \mathrm{C}$ resulted in the highest signal intensity $\left(1.80 \times 10^{7} \mathrm{mV}\right)$.

The column temperature may greatly affect the peak shape, so the post-column ionization efficiency (Guillarme and others, 2004), signal intensity for $\mathrm{m} / \mathrm{z} 163[\mathrm{M}+\mathrm{H}]^{+}$, was tested at different column temperatures $\left(25^{\circ} \mathrm{C}, 35^{\circ} \mathrm{C}\right.$, $45^{\circ} \mathrm{C}, 55^{\circ} \mathrm{C}$ ) using previously optimized chromatographic conditions. The highest signal intensity $\left(2.00 \times 10^{7}\right)$ for $\mathrm{m} / \mathrm{z} 163[\mathrm{M}+\mathrm{H}]^{+}$was observed at $45^{\circ} \mathrm{C}$. This column temperature was then used for sample analyses.

\subsection{Levoglucosan isomers}

As biomass burning produces higher levoglucosan concentration relative to its isomers, galactosan and mannosan (Simoneit and others, 1999; Oros and Simoneit, 2001), levoglucosan concentrations predominated in aerosol, sediment, rain and ice samples (Simoneit, 1999; Elias and others, 2001; Palma and others, 2004; Gambaro and others, 2008). As a result, most studies of biomass burning activities have focused mainly on levoglucosan (Schkolnik and Rudich, 2006).

MS/MS analyses were performed with standard solutions of levoglucosan (100 $\left.\mathrm{ng} \mathrm{mL}^{-1}\right)$, galactosan $\left(100 \mathrm{ng} \mathrm{mL}^{-1}\right)$, mannosan $\left(100 \mathrm{ng} \mathrm{mL}^{-1}\right)$ and one ice-core sample to determine if galactosan and mannosan may contribute significantly to the intensity of $\mathrm{m} / \mathrm{z} 163[\mathrm{M}+\mathrm{H}]^{+}$in our samples. The MS/MS mass spectra of the different isomers and an icecore sample were obtained using $25 \%$ collision energy and are presented in Figure 3. The low ratio of the $\mathrm{m} / \mathrm{z} 85$ versus 89 (with $\mathrm{m} / \mathrm{z} 89$ being characteristic for the levoglucosan and $\mathrm{m} / \mathrm{z} 85$ for its isomers) confirmed a minor contribution of mannosan and galactosan in our Tibetan ice samples. Figure 3 shows a proposed fragmentation scheme that explains the pseudo-molecular ion of levoglucosan, mannosan and galactosan in MS/MS spectrum and the predominance of the ion $\mathrm{m} / \mathrm{z} 89$ in levoglucosan relative to its isomers.

\subsection{Calibration curve, limit of detection and quantification}

The external standard calibration was used to evaluate levoglucosan concentration in the Tibetan ice-core samples. To determine the calibration curve, six levoglucosan standard solutions with concentrations of 40, 100, 200, 500, 800 and $1000 \mathrm{ng} \mathrm{mL}^{-1}$ were injected into the HPLC system and detected by mass spectrometry. The resulting adduct ion $\mathrm{m} / \mathrm{z}$ $163[\mathrm{M}+\mathrm{H}]^{+}$peak areas were used as concentrationdependent response. A well-correlated linear calibration curve was obtained, with a coefficient of determination $\left(R^{2}\right)$ value of 0.9958 .

The limit of detection (LOD) was defined as the concentration of the analyte at $\mathrm{S} / \mathrm{N}=3$ according to the Technical Specification ISO/TS 13530 (ISO, 2009) and was determined as $10 \mathrm{ng} \mathrm{mL}^{-1}$ in the current study. The criterion for the limit of quantification (LOQ) was estimated as three times the LOD with a relative measurement uncertainty of $33 \%$ which was met at $40 \mathrm{ng} \mathrm{mL}^{-1}$.

To identify whether samples measured in series show a chronological dependency, a $200 \mathrm{ng} \mathrm{mL}^{-1}$ standard was measured seven times in one sequence. The Neumann trend test $(P=99 \%)$ applied to the resulting peak areas revealed no trend, and the standard deviation $\left(3 \mathrm{ng} \mathrm{mL}^{-1}\right.$, error $2 \%$ ) of the resulting concentrations showed high precision. Furthermore, a possible time-dependent influence on the results between sequences was examined. Over a period of 1 month a levoglucosan standard was injected 37 times. Again, a Neumann trend test and also a visual check of the plotted data exposed no trend.

16 samples from the Muztagh Ata ice core were analyzed three times to evaluate the repeatability for an individual sample (Table 1). The relative standard deviation (RSD) 


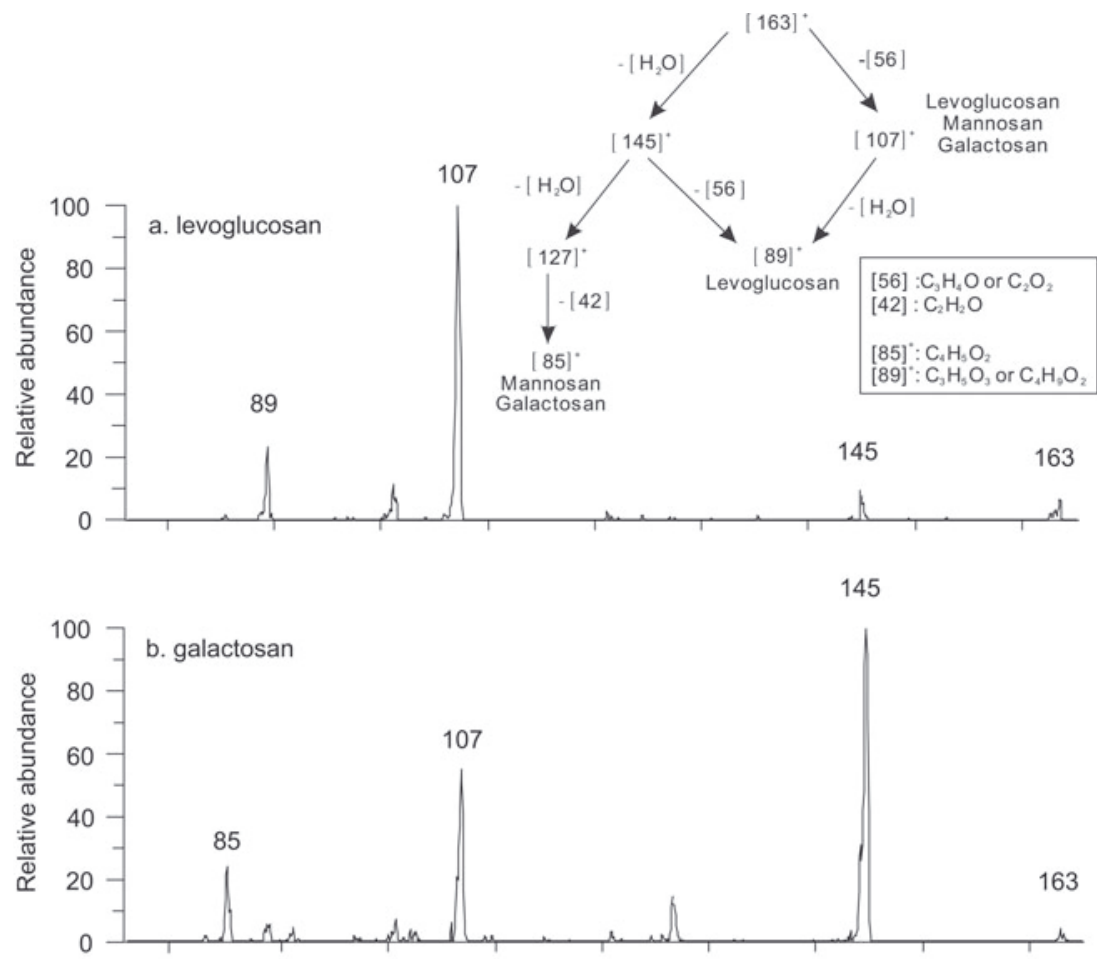

145
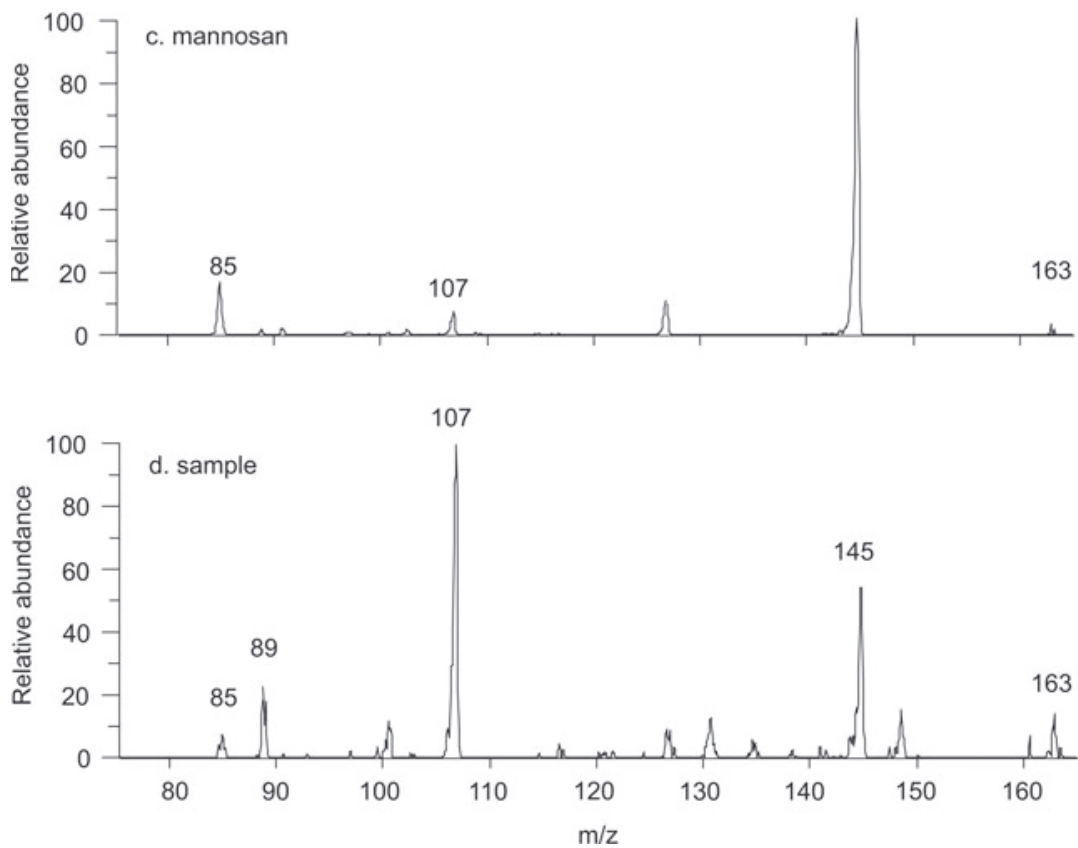

Fig. 3. Proposed fragmentation composition of MS/MS m/z 163 using $25 \%$ collision energy in positive mode (upper right) and spectra of levoglucosan (a), galactosan (b), mannosan (c) and an ice-core sample (d).

ranged from $11 \%$ to $2 \%$, and the average value was $6.8 \%$. All these samples were reanalyzed after 6 months, and the results were at the same concentrations measured before, which suggests there is no significant degradation under a freezing condition of $-20^{\circ} \mathrm{C}$.

Table 2 shows a series of related qualitative and quantitative analyses of levoglucosan from different sample types with different analytical instruments. Although there are no uniform criteria to weigh their performance because of different sample types and detecting systems, the LOD and LOQ of our method were in the lower range of most of the other methods.

\subsection{Levoglucosan in the Tibetan ice-core samples}

A total of 378 samples from the Muztagh Ata ice core from surface to $71 \mathrm{~m}$ depth, and 117 samples from the Tanggula ice core from 1 to $3.5 \mathrm{~m}$ depth, were analyzed using the method introduced above. Levoglucosan concentrations ranged from 10 to $718 \mathrm{ng} \mathrm{mL}^{-1}$ in the Muztagh Ata ice core (Appendix A) and from 10 to $93 \mathrm{ng} \mathrm{mL}^{-1}$ in the Tanggula ice core (Appendix B). The average levoglucosan concentration was 33 and $39 \mathrm{ng} \mathrm{mL}^{-1}$ in the Muztagh Ata and Tanggula ice cores, respectively. The average levoglucosan concentration of $39 \mathrm{ng} \mathrm{mL}^{-1}$ in the Tanggula ice core was $\sim 100$ times higher than those in samples from east Russia (Kawamura 
Table 1. Repeated measurements of levoglucosan concentration in selected samples from the Muztagh Ata ice core

\begin{tabular}{|c|c|c|c|c|c|c|c|}
\hline \multirow[t]{2}{*}{ Sample } & \multirow{2}{*}{$\begin{array}{c}\text { Bottom } \\
\text { depth } \\
\text { m }\end{array}$} & \multicolumn{3}{|c|}{ Levoglucosan conc. } & \multirow{2}{*}{$\begin{array}{l}\text { Ave. } \\
\text { conc. } \\
\text { ng mL }\end{array}$} & \multirow{2}{*}{$\begin{array}{l}\text { Std dev. } \\
\text { ng mL }\end{array}$} & \multirow{2}{*}{$\begin{array}{r}\text { RSD } \\
\\
\%\end{array}$} \\
\hline & & $\begin{array}{c}1 \mathrm{st} \\
\mathrm{ng} \mathrm{mL}^{-1}\end{array}$ & $\begin{array}{c}2 \mathrm{nd} \\
\mathrm{ng} \mathrm{mL}\end{array}$ & $\begin{array}{c}3 \mathrm{rd} \\
\mathrm{ng} \mathrm{mL}\end{array}$ & & & \\
\hline M001 & 0.15 & 19 & 18 & 16 & 18 & 2 & 9 \\
\hline M021 & 3.90 & 17 & 14 & 17 & 16 & 2 & 11 \\
\hline M041 & 7.09 & 29 & 35 & 33 & 32 & 3 & 9 \\
\hline M081 & 14.58 & 137 & 134 & 138 & 136 & 2 & 2 \\
\hline M101 & 18.41 & 137 & 136 & 140 & 138 & 2 & 2 \\
\hline M121 & 21.93 & 24 & 21 & 22 & 22 & 1 & 6 \\
\hline M141 & 25.20 & 25 & 28 & 29 & 27 & 2 & 6 \\
\hline M161 & 28.79 & 15 & 15 & 18 & 16 & 2 & 11 \\
\hline M201 & 36.47 & 60 & 53 & 59 & 57 & 4 & 6 \\
\hline M221 & 39.85 & 141 & 141 & 148 & 143 & 4 & 3 \\
\hline M241 & 43.81 & 18 & 15 & 16 & 16 & 2 & 10 \\
\hline M261 & 47.39 & 53 & 46 & 51 & 50 & 4 & 7 \\
\hline M281 & 51.52 & 32 & 29 & 31 & 31 & 1 & 5 \\
\hline M301 & 55.69 & 27 & 24 & 23 & 24 & 2 & 9 \\
\hline M321 & 59.64 & 32 & 37 & 35 & 35 & 3 & 8 \\
\hline M361 & 67.74 & 84 & 79 & 77 & 80 & 4 & 4 \\
\hline
\end{tabular}

and others, 2012), and 1000 times higher than those in Greenland (Kehrwald and others, 2012). Higher levoglucosan concentrations supported the idea of stronger vulnerability of the Tibetan glaciers to anthropogenic/natural biomass burning events. As biomass burning on the Tibetan Plateau is itself relatively low (Levine, 1991), significant levoglucosan concentrations indicated important transport of continental atmospheric particulate matter from populated Asian zones to the Tibetan Plateau. Located in the western Tibetan Plateau, Muztagh Ata glacier is mainly influenced by the westerly winds that bring air masses from central Asia (Fig. 1) (Wu and others, 2008). The Tanggula Mountains are located in the center of the Tibetan Plateau and receive atmospheric particulates from two different air masses: the westerly winds in winter and the south Asian monsoon from the Indian Ocean in summer (Yang and others, 2007).

Mutztagh Ata glacier has been intensively studied for glacier formations (Yu and others, 2006), paleoclimate (Tian and others, 2006; Duan and others, 2007) and paleoenvironmental studies (Wang and others, 2004; Xiang and others, 2005; Li and others, 2006a; Wu and others 2006, 2008; Liu and others, 2008; Zhao and others, 2008, 2011). Several long ice cores (Tian and others, 2007; Wu and others, 2008; Zhao and others, 2011) in the same altitude range (6350 and $7010 \mathrm{ma.s.l.}$ ) as the studied ice core (6350 m a.s.l) have been accurately dated. The mean annual snow accumulation rate has been calculated as $0.62 \pm$ $0.1 \mathrm{~m}$ w.e. $\mathrm{a}^{-1}$, with a maximum of $1.39 \mathrm{~m}$ in the $1970 \mathrm{~s}$ (Duan and others, 2007). Based on these previous results, we estimate that the entire Muztagh Ata ice core covered a period of $\sim 100$ years.

Distribution of burned areas in central Asia for each decade since 1900 showed three periods of peak-fire events, reaching a strong maximum in the 1990s, and two lower maxima in the 1950s and 1900s (Fig. 4a) (Mouillot and Field, 2005). Although direct comparison between reconstruction

Table 2. Previous studies detecting levoglucosan in various sample types

\begin{tabular}{|c|c|c|c|c|c|c|c|}
\hline Source & Instrument & Ion mode & Target ion & Sample type & RSD & $\begin{array}{l}\mathrm{LOD}^{-1} \\
\mathrm{pg} \mathrm{mL}^{-1}\end{array}$ & $\begin{array}{l}\mathrm{LOQ}^{-1} \\
\mathrm{pg} \mathrm{mL}^{-1}\end{array}$ \\
\hline Piot and others (2012) & GC-MS ${ }^{a}$ & & & Aerosol and soil & $3-5$ & $1 \times 10^{5}$ & $3.33 \times 10^{5}$ \\
\hline Zhang and others (2008) & GC-MS ${ }^{a}$ & & & Aerosol & 4.9 & & \\
\hline Fraser and Lakshmann (2000) & GC-MS ${ }^{a}$ & & & Aerosol & 27 & & \\
\hline Schkolnik and others (2005) & IEC-HPLC-PDA ${ }^{b}$ & & & $\begin{array}{l}\text { Smoke and rain- } \\
\text { water }\end{array}$ & 6 & $5 \times 10^{5}$ & $1 \times 10^{6}$ \\
\hline Engling and others (2006) & HPAEC-PAD ${ }^{c}$ & & & Aerosol & 5.3 & $2 \times 10^{3}$ & \\
\hline Lee and others (2008) & IC-ECD ${ }^{d}$ & & & Aerosol & 4.9 & & \\
\hline Dixon and Baltzell (2006) & HPLC-ACD ${ }^{\mathrm{e}}$ & & & Aerosol & 6.7 & $9 \times 10^{4}$ & \\
\hline Puxbaum and others (2007) & HPLC-ECD ${ }^{f}$ & & & Aerosol & $0.7-1.3$ & & \\
\hline Gao and others (2003) & ESI-MS IC-PADg & + & {$[\mathrm{M}+\mathrm{Na}]^{+}$} & Aerosol & $2-12$ & $6 \times 10^{4}$ & \\
\hline Wan and Yu (2006) & HPLC-MS(ESI) ${ }^{\mathrm{h}}$ & + & {$\left[\mathrm{M}+\mathrm{NH}_{4}\right]^{+}$} & aerosol & $5-26$ & $2 \times 10^{4}$ & \\
\hline Palma and others (2004) & ESI-MS/MS ${ }^{i}$ & - & {$[\mathrm{M}-\mathrm{H}]^{-}$} & Fog water & & & \\
\hline Engling and others (2006) & HPLC-MS(ESI) ${ }^{\mathrm{h}}$ & - & {$\left[\mathrm{M}+\mathrm{CH}_{3} \mathrm{COO}\right]^{-}$} & Aerosol & & & \\
\hline Wan and Yu (2007) & HPLC-MS(ESI) $)^{\mathrm{h}}$ & - & {$[\mathrm{M}+\mathrm{Cl}]^{-}$} & Aerosol & & $1.36 \times 10^{4}$ & \\
\hline Piot and others (2012) & HPLC-MS(ESI) $)^{\mathrm{h}}$ & - & {$[\mathrm{M}-\mathrm{H}]^{-}$} & Aerosol and soil & $5-10$ & $3 \times 10^{4}$ & $1 \times 10^{5}$ \\
\hline Gambaro and others (2008) & HPLC-MS(ESI) ${ }^{\mathrm{h}}$ & - & {$[\mathrm{M}-\mathrm{H}]^{-}$} & Ice & $20-50$ & 3 & \\
\hline Kehrwald and others (2012) & HPLC-MS(ESI) ${ }^{\mathrm{h}}$ & - & {$[\mathrm{M}-\mathrm{H}]^{-}$} & Snow & $2.3-38.2$ & 3 & \\
\hline Kawamura and others (2012) & GC-MS ${ }^{a}$ & & & Ice & & $3-5$ & \\
\hline This study & HPLC-MS(ESI) $)^{\mathrm{h}}$ & + & {$[\mathrm{M}+\mathrm{H}]^{+}$} & Ice & $0.6-10.0$ & $1 \times 10^{4}$ & $4 \times 10^{4}$ \\
\hline
\end{tabular}

\footnotetext{
${ }^{\mathrm{a}}$ Gas chromatography with mass spectrometry.

blon-exclusion chromatography with high-performance liquid chromatography and photodiode array detector.

${ }^{c}$ High-performance anion-exchange chromatography with pulsed amperometric detection.

don chromatography with electrochemical detector.

eHigh-performance liquid chromatography with aerosol charge detection.

${ }^{f} \mathrm{High}$-performance liquid chromatography with electrochemical detector.

${ }^{g}$ Electrospray ionization ion trap mass spectrometry with an ion chromatography pulsed amperometric detector.

${ }^{h}$ High-performance liquid chromatography with electrospray ionization mass spectrometry.

iElectrospray ionization tandem mass spectrometry.
} 

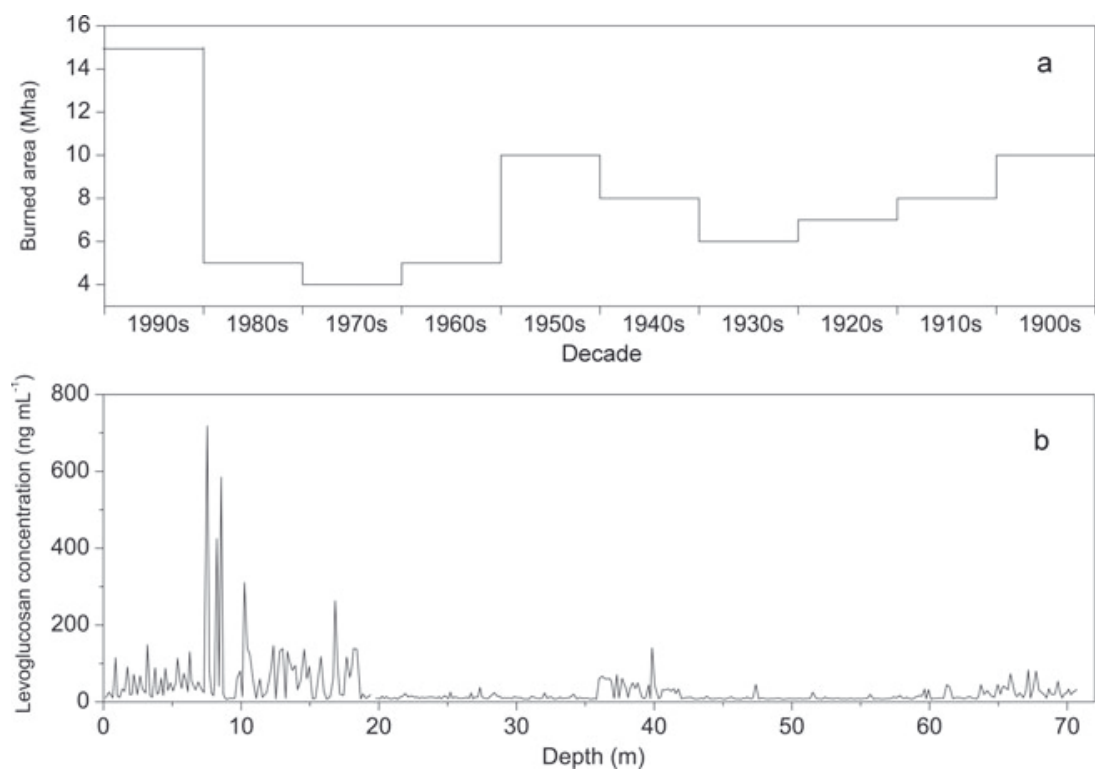

Fig. 4. (a) The temporal trend of burned areas (Mha) in averaged decades for central Asia (modified from Mouillot and Field, 2005). (b) Profile of levoglucosan concentration vs depth in the Muztagh Ata ice core.

of the fire history in central Asia and the levoglucosan concentration-year curve was not possible without exact dating of the core, both curves clearly show similar patterns (Fig. 4b). The strong maximum evidenced in the upper section of the core, and the two lower maxima in the middle and lower core sections (Fig. 4b). The delay between the two curves, which was more important in the upper core section, may result from variations in snow accumulation rates. Further analyses of the Muztagh Ata ice core including $\delta^{18} \mathrm{O}$ and $\mathrm{BC}$ will help to increase the accuracy of the relationships between the two curves.

The chronology of the Tanggula ice core was determined by the maximum value of the $\beta$-activity in 1963 , the seasonal variations of $\delta^{18} \mathrm{O}$ and inorganic ion layers. The core section from 1 to $3.5 \mathrm{~m}$ depth covered 1990-2000 and had an annual net accumulation rate from 33 to $4 \mathrm{~cm} \mathrm{a}^{-1}$ (Appendix B).
During this period, mean annual levoglucosan concentrations, which were calculated based on the weighted net accumulation rate for each year, showed a strong maximum in 1995 and lower maximum in 1997/98 (Fig. 5).

In May-June 1995, 677 700 ha of forest were burned during extreme forest fire events in Uttaranchal and Himachal Pradesh, north India (Kimothi and Jadhav, 1998; Roy, 2004). Using the US National Center for Atmospheric Research (NCAR) reanalysis data from 30 May 1995 (ftp:// arlftp.arlhq.noaa.gov/pub/archives/reanalysis/) and the HYSPLIT (installed version) clustering analyses to track the possible sources of the levoglucosan concentration peak in 1995 in the Tanggula ice core, we demonstrated that $75 \%$ of biomass burning particulates from north India could reach Tanggula glacier in 3-5 days (Fig. 6), which was within the lifetime of levoglucosan in the atmosphere (Fraser and

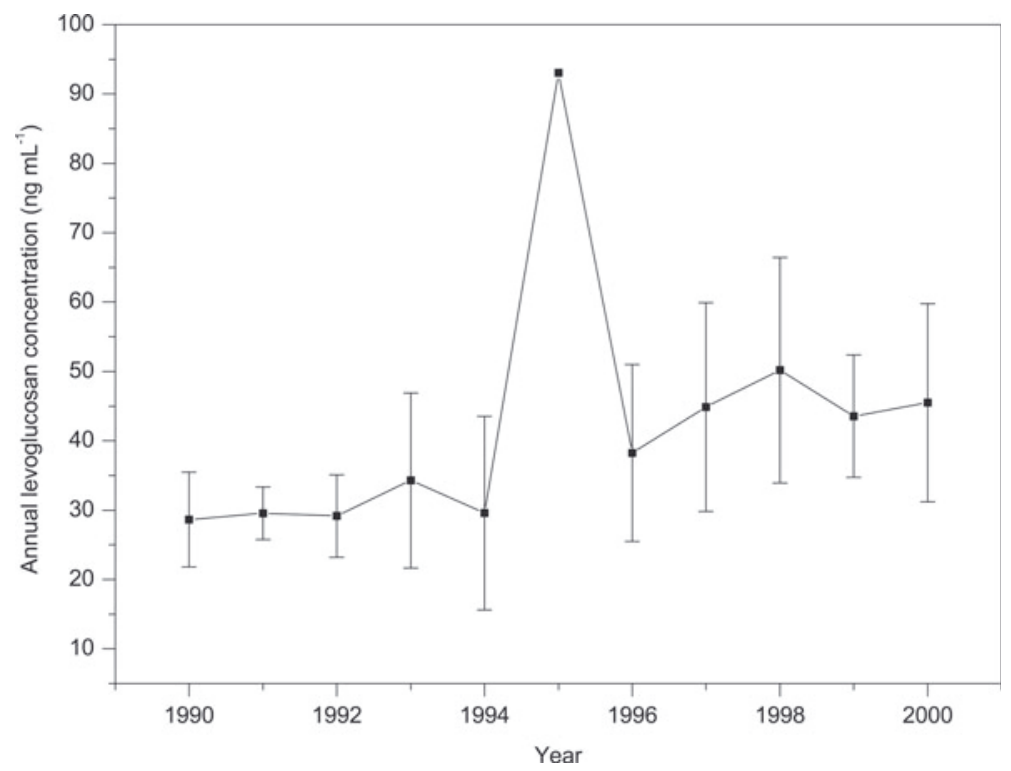

Fig. 5. Temporal variation of annual levoglucosan concentrations with the error bars of standard deviation from 1990 to 2000 in the Tanggula ice core. 


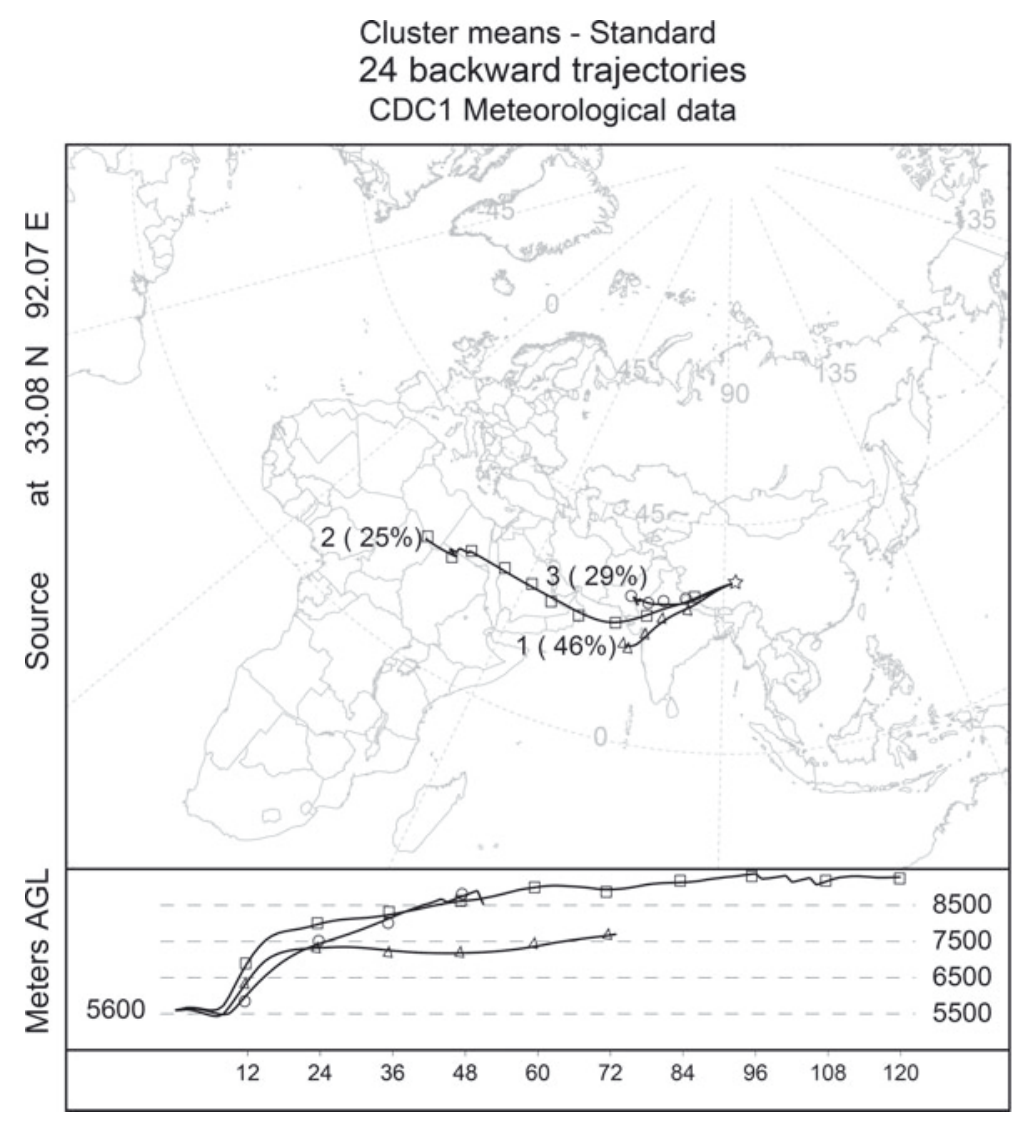

Fig. 6. Five-day backward trajectory analyses at the Tanggula Mountains from 30 May 1995. The trajectory calculations were performed every 12 hours from the Tanggula ice-core site $\left(33^{\circ} 6.6^{\prime} \mathrm{N}, 92^{\circ} 4.4^{\prime} \mathrm{E}\right)$ at $5600 \mathrm{~m}$ a.s.l. using the HYSPLIT model (installed version). The lines with triangles, squares and circles indicate the percent of possible sources.

Lakshmanan, 2000). The El Niño event in 1997/98 triggered widespread drought (De and Mukhopadhyay, 1998; Barlow and others, 2002) which particularly favored fires in 1998 in many regions of the world, including north India (Roy, 2004), China and Indonesia (Van der Werf and others, 2004). This particular condition may thus explain the trend of higher levoglucosan concentrations in 1997/98 in the Tanggula ice core.

The agreement between biomass burning histories in central Asia and the levoglucosan concentrations in the Muztagh Ata ice core, and the extreme fire event in 1995 in north India and the levoglucosan peak concentration in the Tanggula ice core suggest that the westerly winds and the south Asian monsoon were the major sources of atmospheric particulate matter derived from biomass burning in the plateau. Further investigations that will combine levoglucosan concentrations with other biomass burning proxies $\left(\mathrm{K}^{+}, \mathrm{NH}_{4}{ }^{+}\right.$and oxalate) and $\mathrm{BC}$ contents will help us to better assess the role of biomass burning events relative to fossil-fuel burning in the atmospheric particulate matter of the Tibetan Plateau during the past several decades.

\section{CONCLUSION}

A high-performance liquid chromatography with electrospray ionization mass spectrometry method was developed for quantifying levoglucosan in ice-core samples from the Tibetan Plateau. Minimum sample preparation avoided possible error and contamination during the pre-analytical procedure. A large injection volume $(1 \mathrm{~mL})$ was used to decrease the limit of detection in the ice-core samples.
Samples from the Muztagh Ata and Tanggula ice cores showed higher levoglucosan concentrations than those measured in ice or snow samples from Antarctica, Greenland or east Russia. Although an accurate timescale of the Muztagh Ata ice core has not been established, based on the dating of several other ice cores levoglucosan concentrations found in the Muztagh Atga ice core are in good agreement with the biomass burning events in central Asia. However, further work including $\delta^{18} \mathrm{O}$ dating and black carbon quantification will help to better constrain the accuracy of the relationship between the two curves. In the Tanggula ice core, the strong forest fire events in north India in 1995 coincided with the peak of mean annual levoglucosan concentration. These findings suggested that the westerly winds and the south Asia monsoon were the major sources of atmospheric particulate matter derived from biomass burning in the plateau. However, further investigations combining levoglucosan concentrations with other biomass burning proxies and black carbon contents will help to better assess the role of biomass burning events relative to fossil-fuel burning in the atmospheric particulate matter of the Tibetan Plateau.

\section{ACKNOWLEDGEMENTS}

This research was supported by the National Natural Science Foundation of China (40930526, 41125003, 41190081, 41190084). We thank the Max-Planck-Gesellschaft and Chinese Academy of Sciences doctoral promotion program 2010 for financial support of Ping Yao, and the German Research Foundation DFG (1257) for financial support of 
Vanessa-Nina Roth. We thank Susan Trumbore for helpful advice and discussions. We also thank Andrea Gambaro and another reviewer for helpful suggestions. We gratefully acknowledge the US National Oceanic and Atmospheric Administration (NOAA) Air Resources Laboratory (ARL) for provision of the HYSPLIT transport and dispersion model and READY website (http://ready.arl.noaa.gov).

\section{REFERENCES}

Andreae MO and Crutzen PJ (1997) Atmospheric aerosols: biogeochemical sources and role in atmospheric chemistry. Science, 276(5315), 1052-1057

Barlow M, Cullen H and Lyon B (2002) Drought in central and southwest Asia: La Niña, the warm pool, and Indian Ocean precipitation. J. Climate, 15(7), 697-700 (doi: 10.1175/15200442(2002)015<0697:DICASA>2.0.CO;2)

Chiaia AC, Banta-Green C and Field J (2008) Eliminating solid phase extraction with large-volume injection LC/MS/MS: analysis of illlicit and legal drugs and human urine indicators in US wastewaters. Environ. Sci. Technol., 42(23), 8841-8848 (doi: $10.1021 / \mathrm{es} 802309 \mathrm{v})$

De US and Mukhopadhyay RK (1998) Severe heat wave over Indian subcontinent in 1998, in perspective of global climate. Current Sci., 75(12), 1308-1311

Dixon RW and Baltzell G (2006) Determination of levoglucosan in atmospheric aerosols using high performance liquid chromatography with aerosol charge detection. J. Chromatogr. A, 1109(2), 214-221 (doi: 10.1016/j.chroma.2006.01.021)

Duan K, Yao T, Wang N, Tian L, Xu B and Wu H (2007) Records of precipitation in the Muztag Ata ice core and its climate significance to glacier water resources. J. Glaciol. Geocryptol., 29(5). 680-684 [in Chinese]

Dye C and Yttri KE (2005) Determination of monosaccharide anhydrides in atmospheric aerosols by use of high-performance liquid chromatography combined with high-resolution mass spectrometry. Anal. Chem., 77(6), 1853-1858 (doi: 10.1021/ ac049461j)

Elias VO, Simoneit BRT, Cordeiro RC and Turcq B (2001) Evaluating levoglucosan as an indicator of biomass burning in Carajás, amazônia: a comparison to the charcoal record. Geochim. Cosmochim. Acta, 65(2), 267-272 (doi: 10.1016/S00167037(00)00522-6)

Engelhardt $\mathrm{H}$ and Ohs $\mathrm{P}$ (1987) Trace analysis of sugars by HPLC and post-column derivatization. Chromatographia, 23(9), 657-662 (doi: 10.1007/BF02311495)

Engling G and 9 others (2006) Determination of levoglucosan in biomass combustion aerosol by high-performance anionexchange chromatography with pulsed amperometric detection. Atmos. Environ., 40(S2), 299-311 (doi: 10.1016/j.atmosenv. 2005.12.069)

Fabbri D, Torri C, Simoneit BRT, Marynowski L, Rushdi Al and Fabiaéska MJ (2009) Levoglucosan and other cellulose and lignin markers in emissions from burning of Miocene lignites. Atmos. Environ., 43(4), 2286-2295 (doi: 10.1016/j.atmosenv. 2009.01.030)

Fraser MP and Lakshmanan K (2000) Using levoglucosan as a molecular marker for the long-range transport of biomass combustion aerosols. Environ. Sci. Technol., 34(1), 4560-4564 (doi: 10.1021/es991229l)

Gambaro A, Zangrando R, Gabrielli P, Barbante C and Cescon P (2008) Direct determination of levoglucosan at the picogram per milliliter level in Antarctic ice by high-performance liquid chromatography/electrospray ionization triple quadrupole mass spectrometry. Anal. Chem., 80(5), 1649-1655 (doi: 10.1021/ ac701655x)

Gao S, Hegg DA, Hobbs PV, Kirchstetter TW, Magi BI and Sadilek M (2003) Water-soluble organic components in aerosols associated with savanna fires in southern Africa: identification, evolution, and distribution. J. Geophys. Res., 108(D13), 8491 (doi: 10.1029/2002JD002324)

Giannoni $M$ and 7 others (2012) The use of levoglucosan for tracing biomass burning in $\mathrm{PM}_{2.5}$ samples in Tuscany (Italy). Environ. Poll., 167, 7-15 (doi: 10.1016/j.envpol.2012. 03.016)

Guillarme D, Heinisch S and Rocca JL (2004) Effect of temperature in reversed phase liquid chromatography. J. Chromatogr. A, 1052(1-2), 39-51 (doi: 10.1016/j.chroma.2004.08.052)

Hogenboom AC, Hofman MP, Kok SJ, Niessen WMA and Brinkman UATh (2000) Determination of pesticides in vegetables using large-volume injection column liquid chromatography-electrospray tandem mass spectrometry. J. Chromatogr. A, 892(1-2), 379-390 (doi: 10.1016/S0021-9673(00)00182-5)

International Organization for Standardization (ISO) (2009) Water quality - guidance on analytical quality control for chemical and physicochemical water analysis (ISO/TS 13530:2009) International Organization for Standardization, Geneva

Jordan TB, Seen AJ and Jacobsen GE (2006) Levoglucosan as an atmospheric tracer for woodsmoke. Atmos. Environ., 40(27), 5316-5321 (doi: 10.1016/j.atmosenv.2006.03.023)

Kaal J and Rumpel C (2009) Can pyrolysis-GC/MS be used to estimate the degree of thermal alteration of black carbon? Org. Geochem., 40(12), 1179-1187 (doi: 10.1016/j.orggeochem.2009.09.002)

Kaal J, Martinez Cortizas A and Nierop KGJ (2009) Characterisation of aged charcoal using a coil probe pyrolysis-GC/MS method optimised for black carbon. J. Anal. Appl. Pyrolysis, 85(1-2), 408-416 (doi: 10.1016/j.jaap.2008.11.007)

Kawamura K, Izawa Y, Mochida M and Shiraiwa T (2012) Ice core records of biomass burning tracers (levoglucosan and dehydroabietic, vanillic and p-hydroxybenzoic acids) and total organic carbon for past 300 years in the Kamchatka Peninsula, Northeast Asia. Geochim. Cosmochim. Acta, 99, 317-329 (doi: 10.1016/ j.gca.2012.08.006)

Kehrwald N and 6 others (2012) Levoglucosan as a specific marker of fire events in Greenland snow. Tellus B, 64, 18196 (doi: 10.3402/tellusb.v64i0.18196)

Kimothi MM and Jadhav RN (1998) Forest fire in the Central Himalaya: an extent, direction and spread using IRS LISS-I data. Int. J. Remote Sens., 19(12), 2261-2274 (doi: 10.1080/ 014311698214703)

Kuo L-J, Herbert BE and Louchouarn P (2008) Can levoglucosan be used to characterize and quantify char/charcoal black carbon in environmental media? Org. Geochem., 39(10), 1466-1478 (doi: 10.1016/j.orggeochem.2008.04.026)

Lee JJ, Engling G, Lung S-CC and Lee K-Y (2008) Particle size characteristics of levoglucosan in ambient aerosols from rice straw burning. Atmos. Environ., 42(35), 8300-8308 (doi: 10.1016/j.atmosenv.2008.07.047)

Leinonen A, Kuuranne T and Kostianen R (2002) Liquid chromatography/mass spectrometry in anabolic steroid analysis optimization and comparison of three ionization techniques: electrospray ionization, atmospheric pressure chemical ionization and atmospheric pressure photoionization. J. Mass Spectrom., 37(7), 693-698 (doi: 10.1002/jms.328)

Leithead A, Li S-M, Hoff R, Cheng Yand Brook J (2006) Levoglucosan and dehydroabietic acid: evidence of biomass burning impact on aerosols in the Lower Fraser Valley. Atmos. Environ., 40(15), 2721-2734 (doi: 10.1016/j.atmosenv.2005.09.084)

Levine JS (1991) Global biomass burning: atmospheric, climatic, and biospheric implications. MIT Press, Cambridge, MA

Li Y and 6 others (2006a) Recent changes of atmospheric heavy metals in high-elevation ice core from Muxtagh Ata, east Pamirs: initial results. Ann Glaciol., 43, 154-159 (doi: 10.3189/ 172756406781812186)

Li Z, Tao T, Tian L, Xu B and Li Y (2006b) Atmospheric Pb veriations in Central Asia since 1955 from Muztagata ice core record, eastern Pamirs. Chinese Sci. Bull., 51(6), 1996-2000 (doi: 10.1007/s11434-006-2061-9) 
Li X, Xu B, Yao T, Wang N and Wu G (2008) Carbonaceous particles in Muztagh Ata ice core, West Kunlun Mountains, China. Chinese Sci. Bull., 53(21), 3379-3386 (doi: 10.1007/ s11434-008-0294-9)

Morril C, Overpeck JT and Cole JE (2003) A synthesis of abrupt changes in the Asian summer monsoon since the last deglaciation. Holocene, 13(4), 465-476 (doi: 10.1191/ 0959683603hl639ft)

Mouillot F and Field CB (2005) Fire history and the global carbon budget: a $1^{\circ} \times 1^{\circ}$ fire history reconstruction for the 20th century. Global Change Biol., 11(3), 398-420 (doi: 10.1111/j.13652486.2005.00920.x)

Oros DR and Simoneit BRT (2001) Identification and emission factors of molecular tracers in organic aerosols from biomass burning. Part 1. Temperate climate conifers. Appl. Geochem., 16(13), 1513-1544 (doi: 10.1016/S0883-2927(01)00021-X)

Palma P and 7 others (2004) Identification of levoglucosan and related steroisomers in fog water as a biomass combustion tracer by ESI-MS/MS. Ann. Chim., 94(12), 911-919 (doi: 10.1002/ adic.200490113)

Perrone MG and 6 others (2012) Sources of high PM2.5 concentrations in Milan, Northern Italy: molecular marker data and CMB modelling. Sci. Total Environ., 414, 343-355 (doi: 10.1016/j.scitotenv.2011.11.026)

Piot C and 6 others (2012) Quantification of levoglucosan and its isomers by high performance liquid chromatography - electrospray ionization tandem mass spectrometry and its applications to atmospheric and soil samples. Atmos. Measure. Tech., 5(1), 141-148 (doi: 10.5194/amt-5-141-2012)

Puxbaum $\mathrm{H}$ and 8 others (2007) Levoglucosan levels at background sites in Europe for assessing the impact of biomass combustion on the European aerosol background. J. Geophys. Res., 112(D23), D23S05 (doi: 10.1029/2006JD008114)

Rafaëlly L, Héron S, Nowik W and Tchapla A (2008) Optimisation of ESI-MS detection for the HPLC of anthraquinone dyes. Dyes Pigments, 77(1), 191-203 (doi: 10.1016/j.dyepig.2007.05.007)

Roy PS (2004) Forest fire and degradation assessment using satellite remote sensing and geographic information system. In Sivakumar MVK, Roy PS, Harmsen K and Saha SK eds. Satellite Remote Sensing and GIS Applications in Agricultural Meteorology: Proceedings of the Training Workshop, 7-11 July 2003, Dehra Dun, India. World Meteorological Organisation, Geneva, 361-400

Schkolnik G and Rudich Y (2006) Detection and quantification of levoglucosan in atmospheric aerosols: a review. Anal. Bioanal. Chem., 385(1), 26-33 (doi: 10.1007/s00216-005-0168-5)

Schkolnik G, Falkovich AH, Rudich Y, Maenhaut W and Artaxo P (2005) New analytical method for the determination of levoglucosan, polyhydroxy compounds, and 2-methylerythritol and its application to smoke and rainwater samples. Environ. Sci. Technol., 39(8), 2744-2752 (doi: 10.1021/es048363c)

Simoneit BRT (1999) A review of biomarker compounds as source indicators and tracers for air pollution. Environ. Sci. Pollut. Res., 6(3), 159-169 (doi: 10.1007/BF02987621)

Simoneit BRT and 7 others (1999) Levoglucosan, a tracer for cellulose in biomass burning and atmospheric particles. Atmos. Environ., 33(2), 173-182 (doi: 10.1016/S1352-2310 (98)00145-9)

Simoneit BRT, Rogge WF and Jaffé R (2000) Molecular characterization of smoke from campfire burning of pine wood (Pinus elliottii). Chemosphere-Global Change Sci., 2(1), 107-122 (doi: 10.1016/S1465-9972(99)00048-3)

Solomon S and 7 others eds (2007) Climate change 2007: the physical science basis. Contribution of Working Group I to the Fourth Assessment Report of the Intergovernmental Panel on Climate Change. Cambridge University Press, Cambridge

Tian L and 8 others (2006) Recent rapid warming trend revealed from the isotopic record in Muztagata ice core, eastern Pamirs. J. Geophys Res., 111(D13), D1103 (doi: 10.1029/ 2005JD006249)
Tian L, Yao T, Wu G, Li Z, Xu B and Li Y (2007) Chernobyl nuclear accident revealed from the $7010 \mathrm{~m}$ Muztagata ice core record. Chinese Sci. Bull., 52(10), 1436-1439 (doi: 10.1007/s11434007-0188-y)

Van der Werf GR and 7 others (2004) Continental-scale partitioning of fire emissions during the 1997 to 2001 El Niño/La Niña period. Science, 303(5654), 73-76 (doi: 10.1126/science. 1090753)

Wan ECH and Yu JZ (2006) Determination of sugar compounds in atmospheric aerosols by liquid chromatography combined with positive electrospray ionization mass spectrometry. J. Chromatogr. A, 1107(1-2), 175-181 (doi: 10.1016/j.chroma. 2005.12.062)

Wan ECH and Yu JZ (2007) Analysis of sugars and sugar polyols in atmospheric aerosols by chloride attachment in liquid chromatography/negative ion electrospray mass spectrometry. Environ. Sci. Technol., 41(7), 2459-2466 (doi: 10.1021/es062390g)

Wang J, Yao T, Xu B, Wu G and Xiang S (2004) Formate and acetate records in the Muztagata ice core, Northwest Tibetan Plateau. Chinese Sci. Bull., 49(15), 1620-1624 (doi: 10.1007/ BF03184132)

Wolff EW and Peel DA (1985) The record of global pollution in polar snow and ice. Nature, 313(6003), 535-540 (doi: 10.1038/ 313535a0)

Wu G, Yao T, Xu B, Tian L, Li Z and Duan K (2008) Seasonal variations of dust record in the Muztagata ice cores. Chinese Sci. Bull., 53(16), 2506-2512 (doi: 10.1007/s11434-008-0197-5)

Xiang S, Yao TY, An L, Xu B and Wang J (2005) 16S rRNA sequences and differences in bacteria isolated from the Muztag Ata glacier at increasing depths. Appl. Environ. Microbiol., 71(8), 4619-4627 (doi: 10.1128/AEM.71.8.4619-4627.2005)

$\mathrm{Xu} \mathrm{B}$ and 11 others (2009a) Black soot and the survival of Tibetan glaciers. Proc. Natl Acad. Sci. USA (PNAS), 106(52), 22 114-22 118 (doi: 10.1073/pnas.0910444106)

$\mathrm{Xu} \mathrm{B}$ and 7 others (2009b) Deposition of anthropogenic aerosols in a southeastern Tibetan glacier. J. Geophys. Res., 114(D17), D17209 (doi: 10.1029/2008JD011510)

Yang M, Yao T, Gou X, Wang H and Hao L (2007) Comparison analysis of the summer monsoon precipitation between northern and southern slopes of Tanggula Mountains, Qinghai-Xizang (Tibetan) Plateau: a case study in summer 1998. Hydrol. Process., 21(14), 1841-1847 (doi: 10.1002/hyp.6319)

Yu W, Yao T, Tian L, Li Z, Sun W and Wang Y (2006) Relationships between $\delta^{18} \mathrm{O}$ in summer precipitation and temperature and moisture trajectories at Muztagata, western China. Sci. China D, 49(1), 27-35 (doi: 10.1007/s11430-004-5097-1)

Yao T and 14 others (2012) Different glacier status with atmospheric circulations in Tibetan Plateau and surroundings. Nature Climate Change, 2(9), 663-667 (doi: 10.1038/nclimate1580)

Zhang T and 6 others (2008) Identification and estimation of the biomass burning contribution to Beijing aerosol using levoglucosan as a molecular marker. Atmos. Environ., 42(29), 7013-7021 (doi: 10.1016/j.atmosenv.2008.04.050)

Zhao H, Yao T, Xu B, Li Z and Duan K (2008) Ammonium record over the last 96 years from the muztagata glacier in Central Asia. Chinese Sci. Bull., 53(8), 1255-1261 (doi: 10.1007/s11434-0080139-2)

Zhao H, Xu B, Yao T, Tian L and Li Z (2001) Records of sulfate and nitrate in an ice core from Mount Muztagata, central Asia. J. Geophys. Res., 116(D13), D13304 (doi: 10.1029/ 2011JD015735)

Zhu J and Cole RB (2000) Formation and decompositions of chloride adduct ions, $\left[\mathrm{M}+\mathrm{Cl}^{-}\right.$, in negative ion electrospray ionization mass spectrometry. J. Am. Soc. Mass Spectr., 11(11), 932-941 (doi: 10.1016/S1044-0305(00)00164-1)

Zweiner C, Glauner T and Frimmel F (2002) Method optimization for the determination of carbonyl compounds in disinfected water by DNPH derivatization and LC-ESI-MS-MS. Anal. Bioanal. Chem., 372(5-6), 615-621 (doi: 10.1007/s00216002-1233-y) 


\section{APPENDIX A}

Table 3a. Levoglucosan concentrations in the Muztagh Ata ice core with depth (samples M001-M150)

\begin{tabular}{|c|c|c|c|c|c|c|c|c|c|c|c|c|c|c|}
\hline Sample & $\begin{array}{c}\text { Bottom } \\
\text { depth }\end{array}$ & $\begin{array}{l}\text { Levo- } \\
\text { glucosan } \\
\text { conc. } \\
\text { ng mL }\end{array}$ & Sample & $\begin{array}{l}\text { Bottom } \\
\text { depth }\end{array}$ & $\begin{array}{l}\text { Levo- } \\
\text { glucosan } \\
\text { conc. } \\
\text { ng mL }\end{array}$ & Sample & $\begin{array}{l}\text { Bottom } \\
\text { depth }\end{array}$ & $\begin{array}{l}\text { Levo- } \\
\text { glucosan } \\
\text { conc. } \\
\text { ng mL }^{-1}\end{array}$ & Sample & $\begin{array}{l}\text { Bottom } \\
\text { depth }\end{array}$ & $\begin{array}{l}\text { Levo- } \\
\text { glucosan } \\
\text { conc. } \\
\text { ng mL }\end{array}$ & Sample & $\begin{array}{l}\text { Bottom } \\
\text { depth }\end{array}$ & $\begin{array}{l}\text { Levo- } \\
\text { glucosan } \\
\text { conc. } \\
\text { ng mL }\end{array}$ \\
\hline M001 & 0.15 & 19 & M031 & 5.56 & 56 & M061 & 10.45 & 140 & M091 & 16.70 & 61 & M121 & 21.93 & 24 \\
\hline M002 & 0.41 & 26 & M032 & 5.69 & 35 & M062 & 10.64 & 122 & M092 & 16.83 & 263 & M122 & 22.12 & 13 \\
\hline M004 & 0.89 & 115 & M034 & 5.98 & 56 & M064 & 11.09 & 9 & M094 & 17.16 & 21 & M124 & 22.47 & 14 \\
\hline M005 & 0.99 & 17 & M035 & 6.14 & 27 & M065 & 11.37 & 60 & M095 & 17.30 & 18 & M125 & 22.63 & 12 \\
\hline M006 & 1.18 & 12 & M036 & 6.27 & 130 & M066 & 11.55 & 13 & M096 & 17.44 & 17 & M126 & 22.78 & 14 \\
\hline M007 & 1.37 & 34 & M037 & 6.40 & 55 & M067 & 11.85 & 24 & M097 & 17.67 & 117 & M127 & 22.92 & 9 \\
\hline M008 & 1.55 & 28 & M038 & 6.54 & 42 & M068 & 12.02 & 54 & M098 & 17.89 & 64 & M128 & 23.06 & 12 \\
\hline M009 & 1.75 & 91 & M039 & 6.69 & 31 & M069 & 12.18 & 87 & M099 & 18.03 & 86 & M129 & 23.28 & 11 \\
\hline M010 & 1.93 & 19 & M040 & 6.89 & 52 & M070 & 12.35 & 147 & M100 & 18.17 & 139 & M130 & 23.46 & 11 \\
\hline M011 & 2.10 & 21 & M041 & 7.09 & 29 & M071 & 12.52 & 8 & M101 & 18.41 & 137 & M131 & 23.63 & 13 \\
\hline M013 & 2.46 & 19 & M043 & 7.54 & 718 & M073 & 13.03 & 139 & M103 & 18.85 & 21 & M133 & 23.98 & 12 \\
\hline M014 & 2.67 & 68 & M044 & 7.69 & 84 & M074 & 13.23 & 9 & M104 & 19.05 & 10 & M134 & 24.23 & 10 \\
\hline M015 & 2.83 & 34 & M045 & 7.84 & 24 & M075 & 13.36 & 131 & M105 & 19.23 & 13 & M135 & 24.38 & 14 \\
\hline M016 & 3.07 & 23 & M046 & 7.99 & 16 & M076 & 13.51 & 106 & M106 & 19.40 & 18 & M136 & 24.53 & 8 \\
\hline M017 & 3.20 & 149 & M047 & 8.08 & 56 & M077 & 13.72 & 83 & M107 & 19.65 & no data* & M137 & 24.67 & 13 \\
\hline M018 & 3.40 & 16 & M048 & 8.24 & 425 & M078 & 13.94 & 95 & M108 & 19.77 & 9 & M138 & 24.80 & 17 \\
\hline M019 & 3.56 & 13 & M049 & 8.39 & 41 & M079 & 14.10 & 32 & M109 & 19.94 & 9 & M139 & 24.93 & 12 \\
\hline M020 & 3.76 & 89 & M050 & 8.55 & 585 & M080 & 14.33 & 57 & M110 & 20.09 & 8 & M140 & 25.06 & 8 \\
\hline M021 & 3.90 & 17 & M051 & 8.71 & 20 & M081 & 14.58 & 137 & M111 & 20.24 & 15 & M141 & 25.20 & 25 \\
\hline M022 & 4.05 & 26 & M052 & 8.88 & 7 & M082 & 14.77 & 60 & M112 & 20.39 & 9 & M142 & 25.33 & 10 \\
\hline M023 & 4.20 & 62 & M053 & 9.03 & 7 & M083 & 14.95 & 93 & M113 & 20.53 & 14 & M143 & 25.55 & 13 \\
\hline M024 & 4.35 & 17 & M054 & 9.21 & 10 & M084 & 15.19 & 8 & M114 & 20.75 & 9 & M144 & 25.70 & 11 \\
\hline M025 & 4.50 & 88 & M055 & 9.39 & 9 & M085 & 15.39 & 10 & M115 & 20.95 & 8 & M145 & 25.84 & 10 \\
\hline M026 & 4.69 & 30 & M056 & 9.55 & 10 & M086 & 15.55 & 49 & M116 & 21.19 & 11 & M146 & 26.08 & 9 \\
\hline M027 & 4.86 & 50 & M057 & 9.71 & 62 & M087 & 15.79 & 118 & M117 & 21.35 & 7 & M147 & 26.19 & 10 \\
\hline M030 & 5.39 & 114 & M060 & 10.24 & 311 & M090 & 16.47 & 14 & M120 & 21.72 & 14 & M150 & 26.71 & 24 \\
\hline
\end{tabular}

*The volume of sample is not enough to be analyzed.

Table 3b. Levoglucosan concentrations in the Mutzagh Ata ice core with depth (samples M151-M300)

Sample Bottom Levo- Sample Bottom Levo- Sample Bottom Levo- Sample Bottom Levo- Sample Bottom Levodepth glucosan depth glucosan depth glucosan glucosan depth glucosan conc. conc. conc. conc.
$\mathrm{m} \quad \mathrm{ng} \mathrm{mL}^{-1}$
$\mathrm{m} \quad \mathrm{ng} \mathrm{mL} \mathrm{m}^{-1}$
m $\quad n g \mathrm{~mL}^{-1}$
m $\quad n g \mathrm{~mL}^{-1}$
$\mathrm{m} \quad \mathrm{ng} \mathrm{mL} \mathrm{L}^{-1}$

\begin{tabular}{|c|c|c|c|c|c|c|c|c|c|c|c|c|c|c|}
\hline M151 & 26.84 & 8 & M181 & 32.55 & 13 & M211 & 38.25 & 35 & M241 & 43.81 & 18 & M271 & 49.67 & 8 \\
\hline M152 & 26.97 & 12 & M182 & 32.71 & 8 & M212 & 38.44 & 50 & M242 & 44.09 & 8 & M272 & 49.86 & 9 \\
\hline M153 & 27.20 & 12 & M183 & 32.94 & 8 & M213 & 38.64 & 35 & M243 & 44.22 & 8 & M273 & 50.05 & 8 \\
\hline M154 & 27.35 & 38 & M184 & 33.16 & 13 & M214 & 38.80 & 50 & M244 & 44.48 & 8 & M274 & 50.22 & 9 \\
\hline M155 & 27.50 & 13 & M185 & 33.31 & 9 & M215 & 38.97 & 29 & M245 & 44.73 & 10 & M275 & 50.42 & 8 \\
\hline M156 & 27.70 & 10 & M186 & 33.46 & 10 & M216 & 39.09 & 14 & M246 & 44.98 & 8 & M276 & 50.59 & 10 \\
\hline M157 & 27.93 & 9 & M187 & 33.66 & 10 & M217 & 39.24 & 9 & M247 & 45.17 & 7 & M277 & 50.76 & 7 \\
\hline M158 & 28.18 & 17 & M188 & 33.90 & 12 & M218 & 39.38 & 11 & M248 & 45.32 & 10 & M278 & 50.96 & 8 \\
\hline M159 & 28.40 & 24 & M189 & 34.15 & 20 & M219 & 39.60 & 44 & M249 & 45.48 & 11 & M279 & 51.06 & 9 \\
\hline M160 & 28.59 & 15 & M190 & 34.40 & 7 & M220 & 39.73 & 9 & M250 & 45.63 & 13 & M280 & 51.33 & 9 \\
\hline M161 & 28.79 & 15 & M191 & 34.56 & 11 & M221 & 39.85 & 141 & M251 & 45.78 & 9 & M281 & 51.52 & 32 \\
\hline M162 & 28.94 & 9 & M192 & 34.72 & 11 & M222 & 40.05 & 42 & M252 & 45.99 & 8 & M282 & 51.78 & 9 \\
\hline M163 & 29.13 & 11 & M193 & 34.86 & 9 & M223 & 40.32 & 8 & M253 & 46.14 & 8 & M283 & 51.99 & 9 \\
\hline M164 & 29.30 & 10 & M194 & 35.02 & 10 & M224 & 40.47 & 13 & M254 & 46.29 & 7 & M284 & 52.20 & 7 \\
\hline M165 & 29.50 & 10 & M195 & 35.18 & 10 & M225 & 40.60 & 31 & M255 & 46.44 & 10 & M285 & 52.43 & 13 \\
\hline M166 & 29.66 & 9 & M196 & 35.42 & 7 & M226 & 40.80 & 31 & M256 & 46.60 & 9 & M286 & 52.58 & 9 \\
\hline M168 & 30.09 & 11 & M198 & 35.81 & 7 & M228 & 41.22 & 28 & M258 & 46.91 & 9 & M288 & 52.96 & 8 \\
\hline M169 & 30.31 & 12 & M199 & 36.00 & 61 & M229 & 41.44 & 34 & M259 & 47.07 & 8 & M289 & 53.16 & 9 \\
\hline M170 & 30.49 & 8 & M200 & 36.24 & 67 & M230 & 41.57 & 22 & M260 & 47.19 & 11 & M290 & 53.42 & 10 \\
\hline
\end{tabular}


Table 3b. (continued)

\begin{tabular}{|c|c|c|c|c|c|c|c|c|c|c|c|c|c|c|}
\hline Sample & $\begin{array}{c}\text { Bottom } \\
\text { depth }\end{array}$ & $\begin{array}{l}\text { Levo- } \\
\text { glucosan } \\
\text { conc. } \\
\text { ng mL }\end{array}$ & Sample & $\begin{array}{c}\text { Bottom } \\
\text { depth }\end{array}$ & $\begin{array}{l}\text { Levo- } \\
\text { glucosan } \\
\text { conc. } \\
\text { ng mL }\end{array}$ & Sample & $\begin{array}{l}\text { Bottom } \\
\text { depth } \\
\text { m }\end{array}$ & $\begin{array}{l}\text { Levo- } \\
\text { glucosan } \\
\text { conc. } \\
\text { ng mL }\end{array}$ & Sample & $\begin{array}{c}\text { Bottom } \\
\text { depth }\end{array}$ & $\begin{array}{l}\text { Levo- } \\
\text { glucosan } \\
\text { conc. } \\
\text { ng mL }^{-1}\end{array}$ & Sample & $\begin{array}{c}\text { Bottom } \\
\text { depth } \\
\text { m }\end{array}$ & $\begin{array}{l}\text { Levo- } \\
\text { glucosan } \\
\text { conc. } \\
\text { ng mL }\end{array}$ \\
\hline M171 & 30.69 & 8 & M201 & 36.47 & 60 & M231 & 41.77 & 34 & M261 & 47.39 & 53 & M291 & 53.53 & 8 \\
\hline M172 & 30.89 & 7 & M202 & 36.79 & 61 & M232 & 41.99 & 9 & M262 & 47.60 & 8 & M292 & 53.74 & 8 \\
\hline M174 & 31.26 & 13 & M204 & 37.09 & 9 & M234 & 42.55 & 12 & M264 & 48.06 & 9 & M294 & 54.26 & 10 \\
\hline M175 & 31.43 & 10 & M205 & 37.29 & 71 & M235 & 42.75 & 12 & M265 & 48.25 & 7 & M295 & 54.50 & 8 \\
\hline M176 & 31.69 & 9 & M206 & 37.44 & 10 & M236 & 42.91 & 8 & M266 & 48.45 & 9 & M296 & 54.63 & 8 \\
\hline M177 & 31.87 & 10 & M207 & 37.67 & 61 & M237 & 43.06 & 8 & M267 & 48.71 & 8 & M297 & 54.83 & 9 \\
\hline M178 & 32.04 & 23 & M208 & 37.79 & 50 & M238 & 43.27 & 8 & M268 & 49.06 & 11 & M298 & 55.04 & 8 \\
\hline M179 & 32.23 & 9 & M209 & 37.95 & 36 & M239 & 43.43 & 10 & M269 & 49.23 & 8 & M299 & 55.25 & 10 \\
\hline M180 & 32.41 & 13 & M210 & 38.11 & 11 & M240 & 43.59 & 8 & M270 & 49.41 & 7 & M300 & 55.49 & 9 \\
\hline
\end{tabular}

Table 3c. Levoglucosan concentrations in the Mutzagh Ata ice core with depth (samples M301-M378)

\begin{tabular}{|c|c|c|c|c|c|c|c|c|c|c|c|c|c|c|}
\hline Sample & $\begin{array}{c}\text { Bottom } \\
\text { depth }\end{array}$ & $\begin{array}{l}\text { Levo- } \\
\text { glucosan } \\
\text { conc. } \\
\text { ng mL }\end{array}$ & Sample & $\begin{array}{l}\text { Bottom } \\
\text { depth }\end{array}$ & $\begin{array}{l}\text { Levo- } \\
\text { glucosan } \\
\text { conc. } \\
\text { ng mL }\end{array}$ & Sample & $\begin{array}{l}\text { Bottom } \\
\text { depth }\end{array}$ & $\begin{array}{l}\text { Levo- } \\
\text { glucosan } \\
\text { conc. } \\
\text { ng mL }\end{array}$ & Sample & $\begin{array}{l}\text { Bottom } \\
\text { depth }\end{array}$ & $\begin{array}{l}\text { Levo- } \\
\text { glucosan } \\
\text { conc. } \\
\text { ng mL }\end{array}$ & Sample & $\begin{array}{l}\text { Bottom } \\
\text { depth }\end{array}$ & $\begin{array}{l}\text { Levo- } \\
\text { glucosan } \\
\text { conc. } \\
\text { ng mL }\end{array}$ \\
\hline M301 & 55.69 & 27 & M317 & 58.91 & 12 & M333 & 61.97 & 12 & M349 & 65.51 & 38 & M365 & 68.51 & 10 \\
\hline M302 & 55.96 & 7 & M318 & 59.11 & 14 & M334 & 62.24 & 11 & M350 & 65.70 & 32 & M366 & 68.67 & 35 \\
\hline M304 & 56.50 & 7 & M320 & 59.47 & 16 & M336 & 62.69 & 11 & M352 & 66.08 & 42 & M368 & 68.97 & 19 \\
\hline M305 & 56.71 & 8 & M321 & 59.64 & 32 & M337 & 62.87 & 14 & M353 & 66.23 & 19 & M369 & 69.11 & 21 \\
\hline M306 & 56.87 & 8 & M322 & 59.75 & 8 & M338 & 63.15 & 10 & M354 & 66.36 & 14 & M370 & 69.33 & 54 \\
\hline M307 & 57.09 & 9 & M323 & 59.93 & 32 & M339 & 63.43 & 8 & M355 & 66.55 & 24 & M371 & 69.46 & 26 \\
\hline M308 & 57.24 & 9 & M324 & 60.11 & 7 & M340 & 63.58 & 16 & M356 & 66.82 & 11 & M372 & 69.63 & 11 \\
\hline M309 & 57.39 & 13 & M325 & 60.29 & 9 & M341 & 63.73 & 45 & M357 & 67.00 & 29 & M373 & 69.81 & 22 \\
\hline M310 & 57.61 & 11 & M326 & 60.46 & 9 & M342 & 63.96 & 20 & M358 & 67.18 & 83 & M374 & 69.96 & 23 \\
\hline M312 & 58.03 & 10 & M328 & 60.75 & 11 & M344 & 64.48 & 16 & M360 & 67.54 & 35 & M376 & 70.27 & 19 \\
\hline M313 & 58.19 & 9 & M329 & 61.02 & 9 & M345 & 64.72 & 12 & M361 & 67.74 & 84 & M377 & 70.45 & 26 \\
\hline M314 & 58.35 & 13 & M330 & 61.25 & 45 & M346 & 64.95 & 45 & M362 & 67.95 & 31 & M378 & 70.69 & 32 \\
\hline M315 & 58.45 & 10 & M331 & 61.46 & 38 & M347 & 65.15 & 20 & M363 & 68.14 & 25 & & & \\
\hline M316 & 58.73 & 7 & M332 & 61.70 & 8 & M348 & 65.33 & 41 & M364 & 68.35 & 18 & & & \\
\hline
\end{tabular}

\section{APPENDIX B}

Table 4. Levoglucosan concentrations in the Tanggula ice core with depth and chronology (samples T1-10-T3-24)

\begin{tabular}{|c|c|c|c|c|c|c|c|c|c|c|c|}
\hline Sample & $\begin{array}{l}\text { Bottom } \\
\text { depth }\end{array}$ & $\begin{array}{l}\text { Levoglucosan } \\
\text { conc. }\end{array}$ & Year (AD) & $\begin{array}{l}\text { Annual } \\
\text { levoglucosan } \\
\text { conc. }\end{array}$ & Std dev. & Sample & $\begin{array}{l}\text { Bottom } \\
\text { depth }\end{array}$ & $\begin{array}{l}\text { Levoglucosan } \\
\text { conc. }\end{array}$ & Year (AD) & $\begin{array}{l}\text { Annual } \\
\text { levoglucosan } \\
\text { conc. }\end{array}$ & Std dev. \\
\hline & $\mathrm{m}$ & $\mathrm{ng} \mathrm{mL} \mathrm{L}^{-1}$ & & $\mathrm{ng} \mathrm{mL} \mathrm{m}^{-1}$ & $n g \mathrm{~mL}^{-1}$ & & $\mathrm{~m}$ & $\mathrm{ng} \mathrm{mL} L^{-1}$ & & $\mathrm{ng} \mathrm{mL}^{-1}$ & $\mathrm{ng} \mathrm{mL}^{-1}$ \\
\hline T1-10 & 1.07 & 62 & & & & T2-13 & 1.70 & 53 & & & \\
\hline T1-11 & 1.09 & 49 & & & & T2-14 & 1.72 & 80 & & & \\
\hline T1-12 & 1.11 & 66 & & & & T2-15 & 1.74 & 54 & & & \\
\hline T1-13 & 1.14 & 55 & & & & T2-16 & 1.76 & 58 & & & \\
\hline T1-14 & 1.16 & 55 & & & & $\mathrm{~T} 2-17$ & 1.78 & 62 & & & \\
\hline T1-15 & 1.18 & 47 & & & & T2-18 & 1.81 & 32 & & & \\
\hline T1-16 & 1.20 & 23 & & & & T3-01 & 1.84 & 31 & & & \\
\hline T1-17 & 1.22 & 33 & & & & T3-02 & 1.86 & 50 & 1998 & 50 & 16 \\
\hline T1-18 & 1.24 & 31 & & & & T3-03 & 1.88 & 22 & & & \\
\hline T1-19 & 1.26 & 35 & & & & T3-04 & 1.90 & 33 & & & \\
\hline T1-21 & 1.31 & no data* & 2000 & 45 & 14 & T3-06 & 1.94 & 25 & & & \\
\hline T1-22 & 1.33 & no data* & & & & T3-07 & 1.96 & 35 & & & \\
\hline
\end{tabular}


Table 4. (continued)

\begin{tabular}{|c|c|c|c|c|c|c|c|c|c|c|c|}
\hline Sample & $\begin{array}{l}\text { Bottom } \\
\text { depth }\end{array}$ & $\begin{array}{l}\text { Levoglucosan } \\
\text { conc. }\end{array}$ & Year (AD) & $\begin{array}{l}\text { Annual } \\
\text { levoglucosan } \\
\text { conc. }\end{array}$ & Std dev. & Sample & $\begin{array}{c}\text { Bottom } \\
\text { depth }\end{array}$ & $\begin{array}{l}\text { Levoglucosan } \\
\text { conc. }\end{array}$ & Year (AD) & $\begin{array}{l}\text { Annual } \\
\text { levoglucosan } \\
\text { conc. }\end{array}$ & Std dev. \\
\hline T1-23 & 1.35 & no data* & & & & T3-08 & 1.98 & 57 & & & \\
\hline T1-24 & 1.37 & no data* & & & & T3-09 & 2.00 & 58 & & & \\
\hline T1-25 & 1.39 & 34 & & & & T3-10 & 2.03 & 66 & & & \\
\hline T1-26 & 1.41 & 48 & & & & T3-11 & 2.05 & 40 & & & \\
\hline T1-27 & 1.44 & 44 & & & & T3-12 & 2.07 & 62 & & & \\
\hline T2-01 & 1.46 & 36 & & & & T3-13 & 2.09 & 61 & & & \\
\hline T2-02 & 1.48 & no data* & & & & T3-14 & 2.11 & 63 & & & \\
\hline T2-03 & 1.50 & no data* & & & & T3-15 & 2.13 & 51 & & & \\
\hline T2-04 & 1.52 & 56 & 1999 & 44 & 9 & T3-16 & 2.15 & 43 & & & \\
\hline T2-05 & 1.54 & 25 & & & & T3-17 & 2.17 & 28 & & & \\
\hline T2-07 & 1.58 & 59 & & & & T3-19 & 2.21 & 31 & & & \\
\hline T2-08 & 1.60 & 46 & & & & T3-20 & 2.23 & 29 & & & \\
\hline T2-09 & 1.62 & 41 & & & & T3-21 & 2.25 & no data* & & & \\
\hline T2-10 & 1.64 & 32 & & & & T3-22 & 2.28 & no data* & & & \\
\hline T2-11 & 1.66 & 66 & & & & T3-23 & 2.30 & 48 & & & \\
\hline $\mathrm{T} 2-12$ & 1.68 & 76 & & & & T3-24 & 2.32 & 42 & & & \\
\hline
\end{tabular}

*The volume of sample is not enough to be analyzed.

MS received 27 February 2013 and accepted in revised form 11 April 2013 